\title{
Thermal Stability of Ionic Liquids: Current Status and Prospects for Future Development
}

\author{
Chenqian $\mathrm{Xu}$ (D) and Zhenmin Cheng *
}

check for

updates

Citation: Xu, C.; Cheng, Z. Thermal Stability of Ionic Liquids: Current Status and Prospects for Future Development. Processes 2021, 9, 337. https://doi.org/10.3390/pr9020337

Academic Editor: Andrew S. Paluch

Received: 22 January 2021

Accepted: 9 February 2021

Published: 12 February 2021

Publisher's Note: MDPI stays neutral with regard to jurisdictional claims in published maps and institutional affiliations.

Copyright: (C) 2021 by the authors Licensee MDPI, Basel, Switzerland. This article is an open access article distributed under the terms and conditions of the Creative Commons Attribution (CC BY) license (https:/ / creativecommons.org/licenses/by/ $4.0 /)$.
State Key Laboratory of Chemical Engineering, School of Chemical Engineering, East China University of Science and Technology, Shanghai 200237, China; chenqianxuci@gmail.com

* Correspondence: zmcheng@ecust.edu.cn; Tel.: +86-21-64253529

\begin{abstract}
Ionic liquids (ILs) are the safest solvent in various high-temperature applications due to their non-flammable properties. In order to obtain their thermal stability properties, thermogravimetric analysis (TGA) is extensively used to analyze the kinetics of the thermal decomposition process. This review summarizes the different kinetics analysis methods and finds the isoconversional methods are superior to the Arrhenius methods in calculating the activation energy, and two tools-the compensation effect and master plots-are suggested for the calculation of the pre-exponential factor. With both parameters, the maximum operating temperature (MOT) can be calculated to predict the thermal stability in long-term runnings. The collection of thermal stability data of ILs with divergent cations and anions shows the structure of cations such as alkyl side chains, functional groups, and alkyl substituents will affect the thermal stability, but their influence is less than that of anions. To develop ILs with superior thermal stability, dicationic ILs (DILs) are recommended, and typically, $\left[\mathrm{C}_{4}(\mathrm{MIM})_{2}\right]\left[\mathrm{NTf}_{2}\right]_{2}$ has a decomposition temperature as high as $468.1^{\circ} \mathrm{C}$. For the convenience of application, thermal stability on the decomposition temperature and thermal decomposition activation energy of $130 \mathrm{ILs}$ are summarized at the end of this manuscript.
\end{abstract}

Keywords: ionic liquid; thermal stability; thermal decomposition kinetics; dicationic ionic liquid

\section{Introduction}

Ionic liquids (ILs) are molten salts at room temperature composed of organic cations and organic/inorganic anions [1,2]. ILs have been described as "designer solvents" because their physicochemical property can be regulated or tailor-made by changing their constituents or the structures of the pairs of the ions [3-5]. Previous research has proved that ILs have many advantages, including non-volatility, non-flammability, high thermal and chemical stability, wide electrochemical window, tunable miscibility, and good extraction capability, which are not attained for the volatile organic solvents [6-8]. As a result of these features and advantages, ILs are used in a wide range of applications such as catalyst [9-14], pre-treatment of biomass [15-17], absorbent [18-20], gas sensors [21], electrolyte [22-24], and membrane separation [25-27]. Among all of the applications, high-temperature utilization accounts for the vast majority, including high-temperature lubricants [28-30], solvents for high-temperature organic reactions [31], heat-transfer fluids [32,33], and thermal energy storage $[34,35]$. Although ILs are generally considered to be thermally stable, yet their stability is influenced seriously by a lot of factors.

So far, the thermal stability of ILs has been studied by many techniques, such as UV (ultraviolet)-vis spectroscopy [36], flame ionization detection (FID) [37,38], and mass spectrometry (MS) [39-41]. Moreover, in some studies, ILs are heated isothermally in a furnace and open to air to simulate the real environment $[42,43]$. In order to quantitatively evaluate the thermal stability of ILs, parameters accounting for short-term and long-term thermal stability are obtained by thermogravimetric analysis (TGA), and the most representative ones are the onset decomposition temperature $\mathrm{T}_{\text {onset }}$ and $\mathrm{T}_{\mathrm{z} / \mathrm{y}}$ (decomposition degree $z$ 
in a selected time $y$ ), respectively. Although many studies have indicated $\mathrm{T}_{\text {onset }}$ obtained by dynamic TGA overestimates the thermal stability $[36,39,44]$, it is still widely used to express the stability of ILs from divergent papers $[45,46]$. Despite the long-term isothermal experiments can more accurately reflect the real stability of ILs [44,47-49], but it should be noted that the time in these experiments is still far less than the heat exposure time in many real applications. To provide the method in predicting long-term thermal stability, different models have been developed [50-52].

To solve the problem when the entire sample cannot be decomposed $[47,48]$, nonisothermal TGA is developed as the most popular method to determine the kinetic parameters in the thermal decomposition process, and the combination of TGA data allows researchers to calculate the activation energy and pre-exponential factor in this process. Arrhenius methods are widely used in kinetics analysis due to their simple calculation process. However, some recent studies have used the isoconversional methods to calculate the activation energy $[44,53,54]$, while the methods of compensation effect and master plots provide the pre-exponential factor calculation [55-57].

The thermal stability of ILs is mainly determined by the structure of anions and cations, and anions usually play a major role [46,58,59]. However, more studies are focused on the modification of cations, including alkyl chain length, functional groups, and alkyl substituents to improve the thermal stability of ILs [60,61]. Other conditions, such as gas atmosphere, heating rates, and impurities, also influence the thermal stability measurements $[45,62]$. Among which, the heating rate has the most significant impact on the TGA results, and the difference in $\mathrm{T}_{\text {onset }}$ obtained at $1{ }^{\circ} \mathrm{C} / \mathrm{min}$ and $20^{\circ} \mathrm{C} / \mathrm{min}$ is even up to $100{ }^{\circ} \mathrm{C}$ [44]. Finally, ILs mixtures and dicationic ILs (DILs) are introduced as potential applications for the further development of high-temperature ILs.

\section{Measurement of Thermal Stability}

\subsection{Short-Term Thermal Stability}

Dynamic TGA is applied in the study for short-term thermal stability measurement, and the most common heating rate is $10{ }^{\circ} \mathrm{C} / \mathrm{min}[36,39,42,63-66]$. Effects of different heating rates, at $5,10,15,20^{\circ} \mathrm{C} / \mathrm{min}$ are available in previous studies, and it should be noted that the faster the heating rate is, the more overestimated the thermal stability of ILs is, and the corresponding dynamic TGA curve will move to the right accordingly. [18,39,49,53,57].

$\mathrm{T}_{\text {onset }}$, which is basically known as the short-term thermal stability, is determined by dynamic TGA. Moreover, it is a value calculated by the thermal analysis software, which is defined as the intersection of the baseline of zero weight loss and the tangent of the weight versus temperature curve as decomposition occurs [45]. Therefore, the temperature at which the sample begins to decompose is lower than $T_{\text {onset. }} T_{z}$ (decomposition degree $z$ ) is also a parameter to characterize the short-term thermal stability, which directly shows the temperatures at different decomposition degrees [55,63,67-69]. Both parameters are illustrated clearly in Figure 1. In fact, the difference between $\mathrm{T}_{\text {onset }}$ and $\mathrm{T}_{50 \%}$ or $\mathrm{T}_{10 \%}$ is a measure of the decomposition rate, and the lower the temperature difference between $\mathrm{T}_{\text {onset }}$ and $\mathrm{T}_{50 \%}$ or $\mathrm{T}_{10 \%}$, the lower the stability of the ionic liquid [70]. 


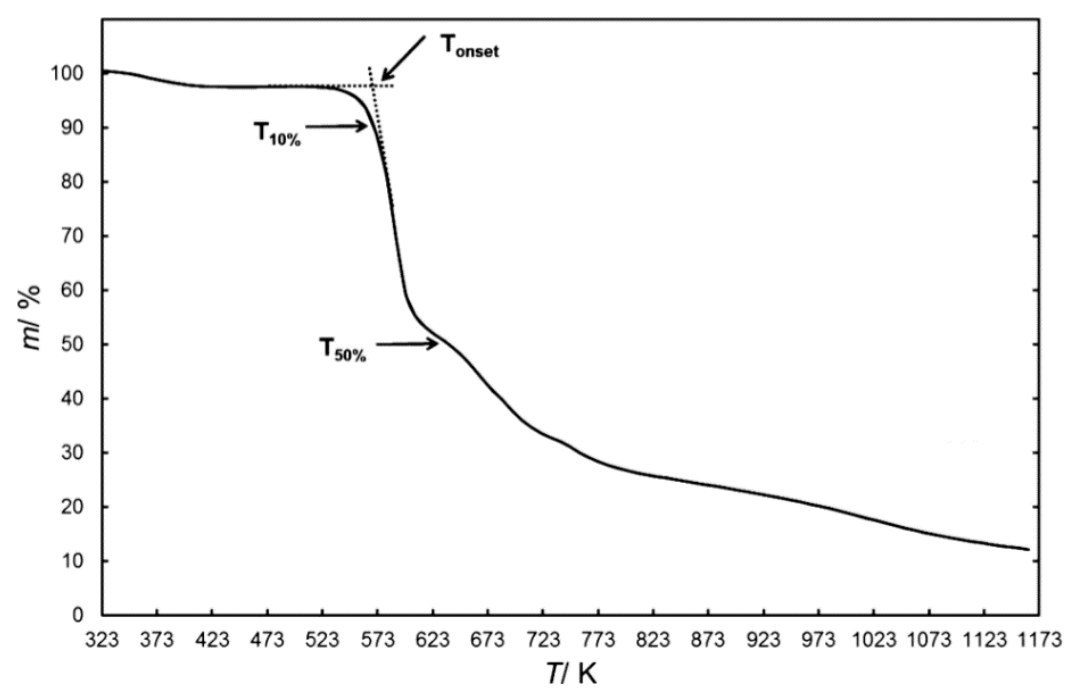

Figure 1. Thermal parameters of ionic liquids (ILs) obtained from dynamic thermogravimetric analysis (TGA) curves [70].

Another method to investigate the short-term thermal stability called derivative thermogravimetry (DTG) is shown in Figure 2. It determines the temperature of maximum degradation $\mathrm{T}_{\text {peak }}[42,64,71-73]$, i.e., if there is one more peak in the DTG curve, the temperature corresponding to the highest peak will be selected [74]. The number of peaks in a DTG curve is also an important parameter. Most ILs have only one peak, indicating the decomposition process is a simple one-step process [44], and two peaks in some DTG curves correspond to two different degradation processes in the sample [63].

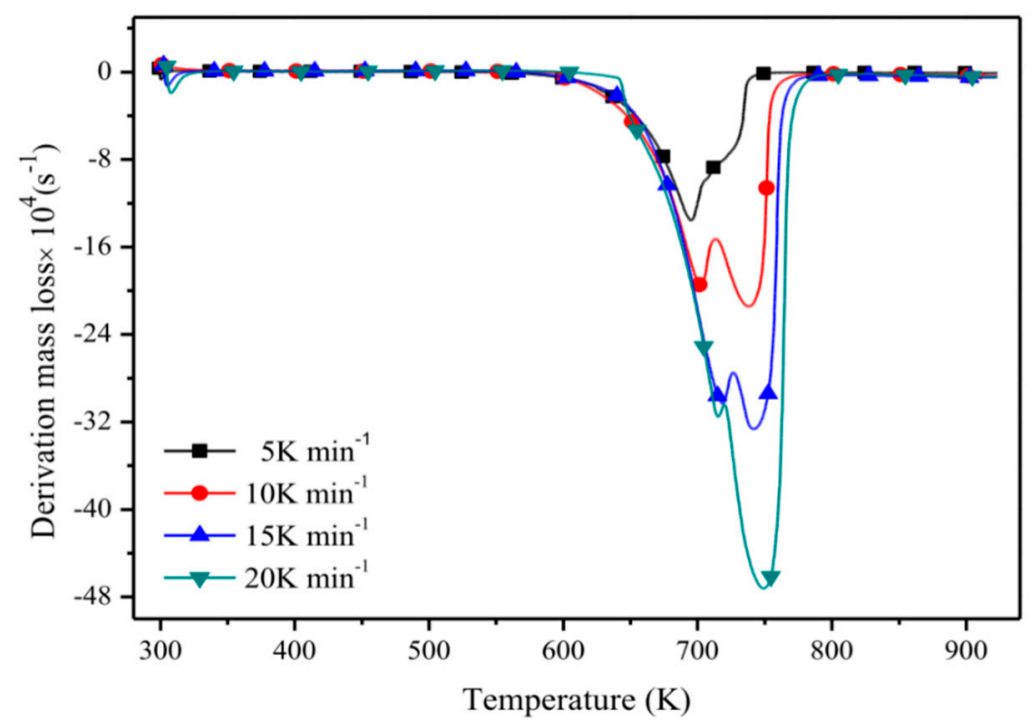

Figure 2. Derivative thermogravimetry (DTG) curves of $\left[\mathrm{C}_{4} \mathrm{MIM}\right]\left[\mathrm{NTf}_{2}\right]$ [18].

\subsection{Long-Term Thermal Stability}

Although $\mathrm{T}_{\text {onset }}$ is widely used to describe the thermal stability of ILs, it is not a suitable parameter for long-term industrial applications. To establish the correlation between the operating temperature and time, it is necessary to investigate the long-term thermal stability of ILs through isothermal TGA $[36,75,76]$. In this method, samples are heated at a fixed temperature varying from an hour to tens of hours, then $T_{z / y}$ is determined $[49,57,77-79]$. As shown in Figure 3, more than three temperatures are usually used in the analysis [75,78], and the interval between different temperatures is determined by $\mathrm{T}_{\text {onset }}$ [74]. However, it is much shorter than the cycle of industrial runnings. Neither extrapolating experimental data 
nor extending the heating time of isothermal TGA seems to be the best solution. Therefore, some means predicting the long-term thermal stability of ILs have been proposed.

(a)

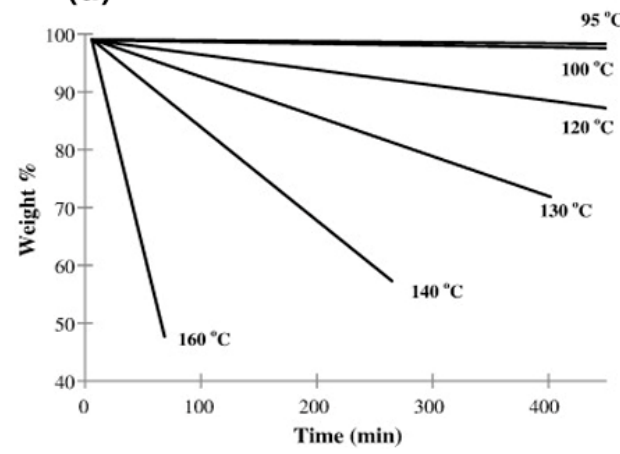

(b)

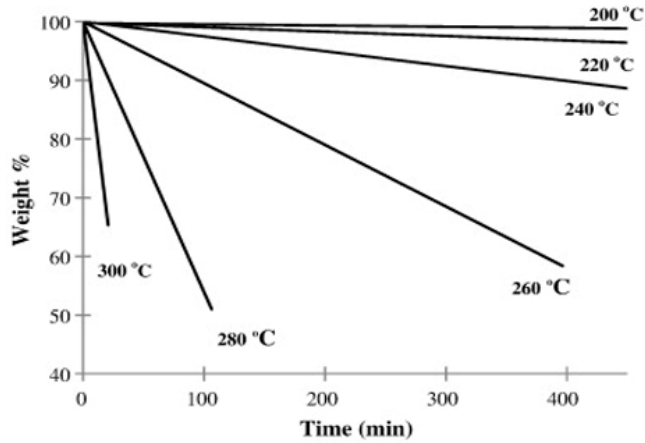

(c)

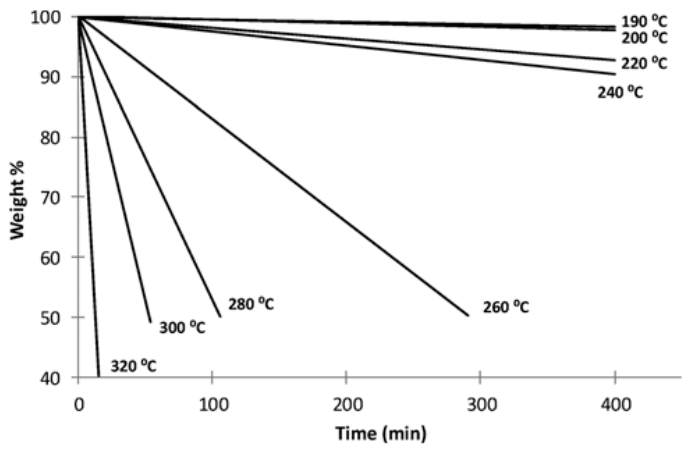

Figure 3. Isothermal TGA for (a) 4-methyl-1-propyl-1,2,4-triazolium iodide, (b) 4-methyl-1-propyl-1,2,4-triazolium triflate, and (c) 1-butyl-4-methyl-1,2,4-triazolium [NTf 2$]$ in nitrogen atmosphere [75,78].

Seeberger et al. [50] proposed using the maximum operating temperature (MOT) to measure the long-term thermal stability at $1 \%$ decomposition degree, which is

$$
\mathrm{MOT}=\frac{E}{R \cdot\left[4.6+\ln \left(A \cdot t_{\max }\right)\right]}
$$

where $A$ denotes the pre-exponential factor, $E$ is the activation energy, $R$ is the universal gas constant, and $t_{\max }$ is the maximum operation time. MOT has been used to predict the long-term thermal stability successfully in several recent studies [56,71,73]. Moreover, MOT is also applied in the prediction of the thermal stability of ILs mixtures [80].

To estimate the maximum time for ILs used under a specific temperature, Salgado et al. [51] proposed an exponential function of the temperature, similar to Cao and $\mathrm{Mu}$ [74], which is

$$
t=B e^{C T}
$$

where $t$ is the time in minutes, $B$ and $C$ are the fitting parameters, and $T$ is the scanning temperature in K. From isothermal TGA, $t$, that each IL takes to decompose to a certain percentage of mass, is determined at different $T$. This equation can quantitatively describe the relationship between the decomposition temperature and the decomposition time of ILs under a certain degree of decomposition. With this method, $T_{0.01 / 10 \mathrm{~h}}, T_{0.05 / 10 \mathrm{~h}}$, and $T_{0.1 / 10 \mathrm{~h}}$ have been correlated, and $T_{0.01 / 10 \mathrm{~h}}$ was given by Wooster et al. [52] according to

$$
T_{0.01 / 10 h} \approx 0.82 T_{(d w / d T \neq 0)}
$$

where $T_{(d w / d T \neq 0)}$ is the temperature at which the first appreciable weight loss occurs. The results of $T_{0.01 / 10 h}$ calculated by Equation (2) is higher than that by Equation (3), which 
attributes to the different experimental conditions [51]. In another research, the above three methods are used to calculate $T_{0.01 / 10 h}$ of some aprotic ILs [63]. The experiments prove that the results obtained by Wooster's method (Equation (3)) are the highest, followed by Salgado's method (Equation (2)), and those calculated by Seeberger's method (Equation (1)) are the lowest.

\subsection{Factors Affecting TGA Results}

\subsubsection{Heating Rates}

In dynamic TGA, $T_{\text {onset }}$ varies significantly with different heating rates, since when the temperature rises rapidly, it will easily exceed the onset decomposition temperature, resulting in a mass loss that cannot be measured correctly [50]. As shown in Figure 4, compared with a slower heating rate, the higher $\mathrm{T}_{\text {onset }}$ is obtained at a faster heating rate [57]. For $\left[\mathrm{C}_{2} \mathrm{MIM}\right]\left[\mathrm{NTf}_{2}\right]$ and $\left[\mathrm{C}_{3} \mathrm{MIM}\right]\left[\mathrm{NTf}_{2}\right]$, it is found that the difference of $\mathrm{T}_{\text {onset }}$ obtained at $1{ }^{\circ} \mathrm{C} / \mathrm{min}$ and $20^{\circ} \mathrm{C} / \mathrm{min}$ is $100^{\circ} \mathrm{C}$ [44]. This trend has also been found in more investigations $[39,54]$. Therefore, it is necessary to pay attention to the heating rate when comparing $\mathrm{T}_{\text {onset }}$ by different authors. As a criterion, most of the literature known to date gives the $\mathrm{T}_{\text {onset }}$ value at $10^{\circ} \mathrm{C} / \mathrm{min}$.

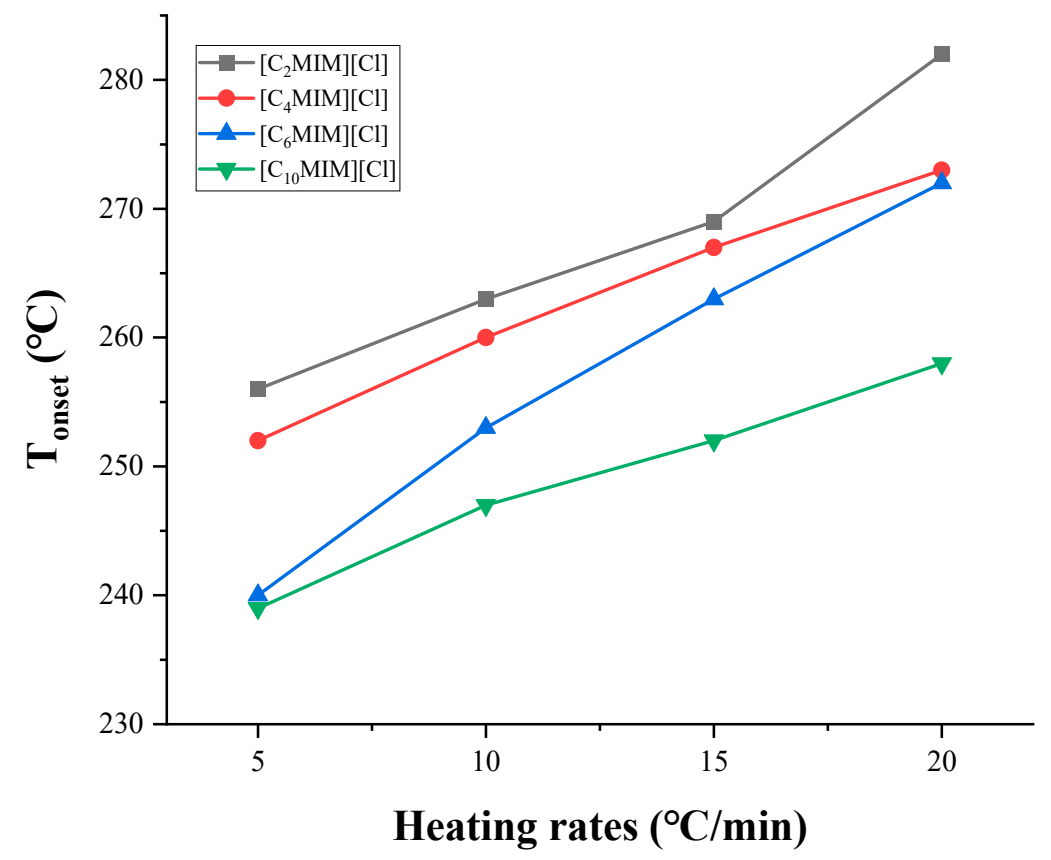

Figure 4. $\mathrm{T}_{\text {onset }}$ measured at different heating rates [57].

\subsubsection{Gas Atmosphere}

$\mathrm{N}_{2}$ is often chosen as the gas atmosphere in TGA, while it is just a special case in industrial applications. Therefore, it is necessary to figure out the influence of different gas atmospheres on the thermal stability of ILs. As shown by Götz et al., the TGA results of $\left[\mathrm{P}_{14,6,6,6}\right]\left[\mathrm{NTf}_{2}\right]$ indicate the mass loss in $\mathrm{H}_{2}$ is much higher than that in $\mathrm{N}_{2}$ at the same temperature, i.e., $\mathrm{H}_{2}$ accelerates the decomposition of $\left[\mathrm{P}_{14,6,6,6}\right]\left[\mathrm{NTf}_{2}\right]$ [6]. Figure 5 shows some $\mathrm{T}_{\text {onset }}$ and $\mathrm{T}_{10 \%}$ obtained in both $\mathrm{N}_{2}$ and $\mathrm{O}_{2}$ atmospheres. The results reveal that the $\mathrm{T}_{\text {onset }}$ and $\mathrm{T}_{10 \%}$ of $\left[\mathrm{NTf}_{2}\right]^{-}$ILs obtained in $\mathrm{O}_{2}$ are lower by $38^{\circ} \mathrm{C}$ to $97^{\circ} \mathrm{C}$ than those obtained in $\mathrm{N}_{2}$, indicating the reactive atmosphere reduces their thermal stability [49]. The effect of air on thermal stability is similar to that of $\mathrm{O}_{2}$. As shown in Figure 6, $\left[\mathrm{P}_{4,4,4,8}\right][\mathrm{BScB}]$ and $\left[\mathrm{P}_{4,4,4,8}\right][\mathrm{BMB}]$ are more thermally stable in $\mathrm{N}_{2}$ than in air [81], and the same results are observed in another study [55]. However, according to Figure 7 , the $\mathrm{T}_{\text {onset }}$ of some choline, pyridinium, and phosphonium ILs are not significantly affected by gas atmospheres, and the maximum temperature difference is only $26^{\circ} \mathrm{C}[40,73]$. 


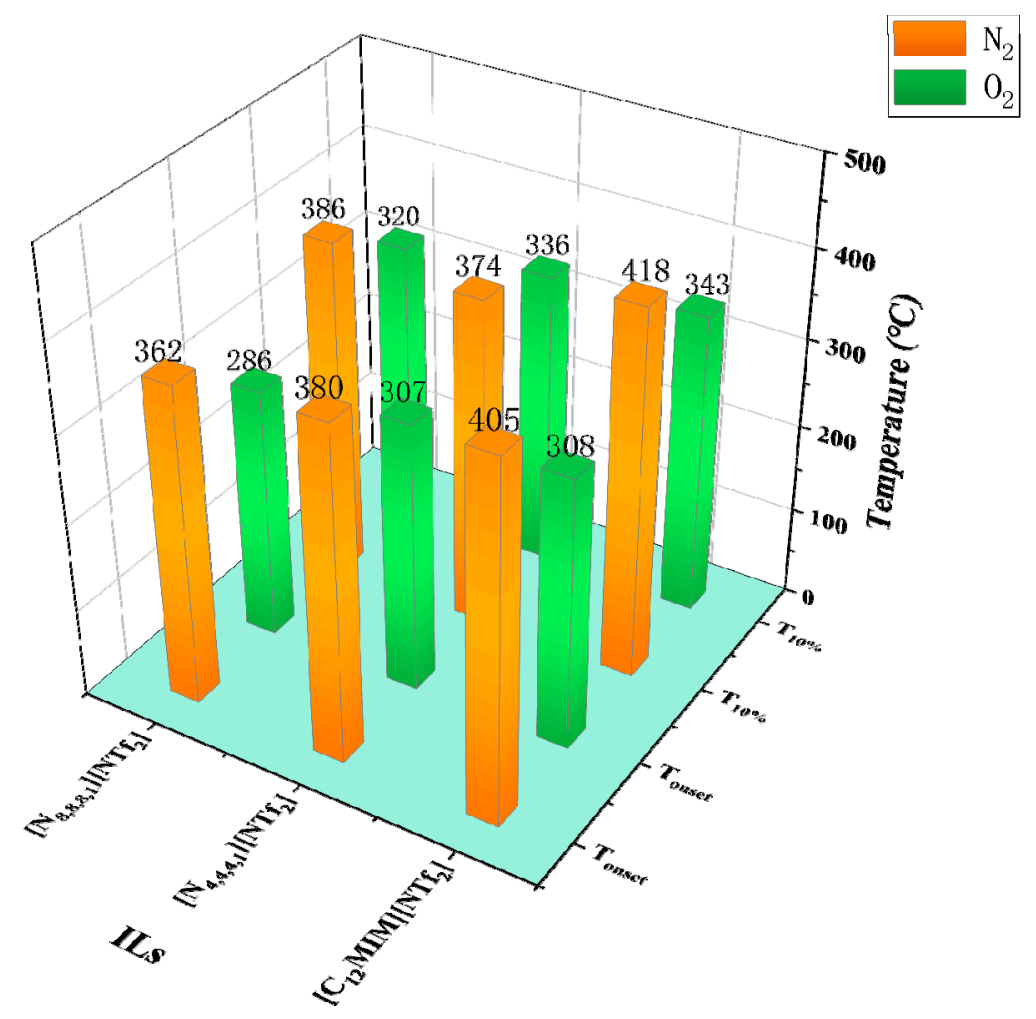

Figure 5. $\mathrm{T}_{\text {onset }}$ and $\mathrm{T}_{10 \%}$ of $\left[\mathrm{NTf}_{2}\right]^{-}$ILs in $\mathrm{N}_{2}$ and $\mathrm{O}_{2}$ at a heating rate of $10{ }^{\circ} \mathrm{C} / \mathrm{min}$ [49].

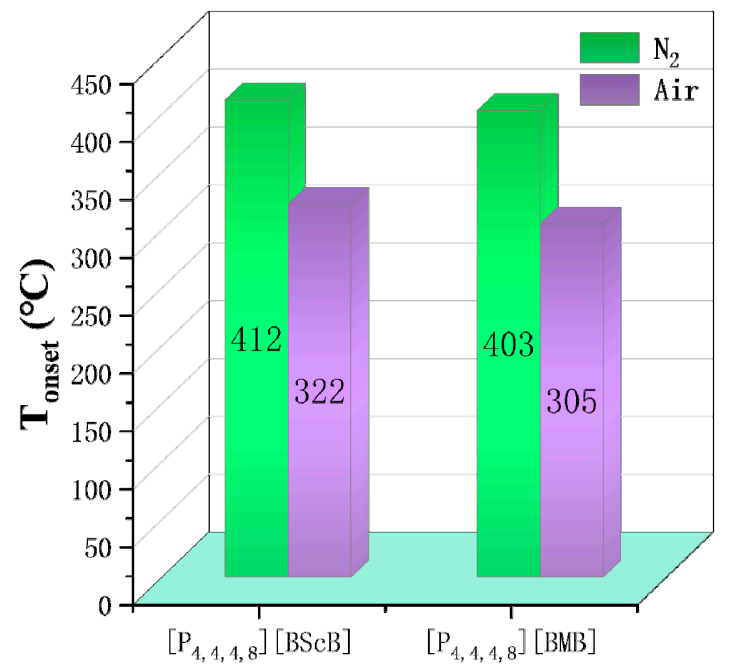

ILs

Figure 6. $\mathrm{T}_{\text {onset }}$ of $\left[\mathrm{P}_{4,4,4,8}\right][\mathrm{BScB}]$ and $\left[\mathrm{P}_{4,4,4,8}\right][\mathrm{BMB}]$ in $\mathrm{N}_{2}$ and air at a heating rate of $10^{\circ} \mathrm{C} / \mathrm{min}[81]$. 


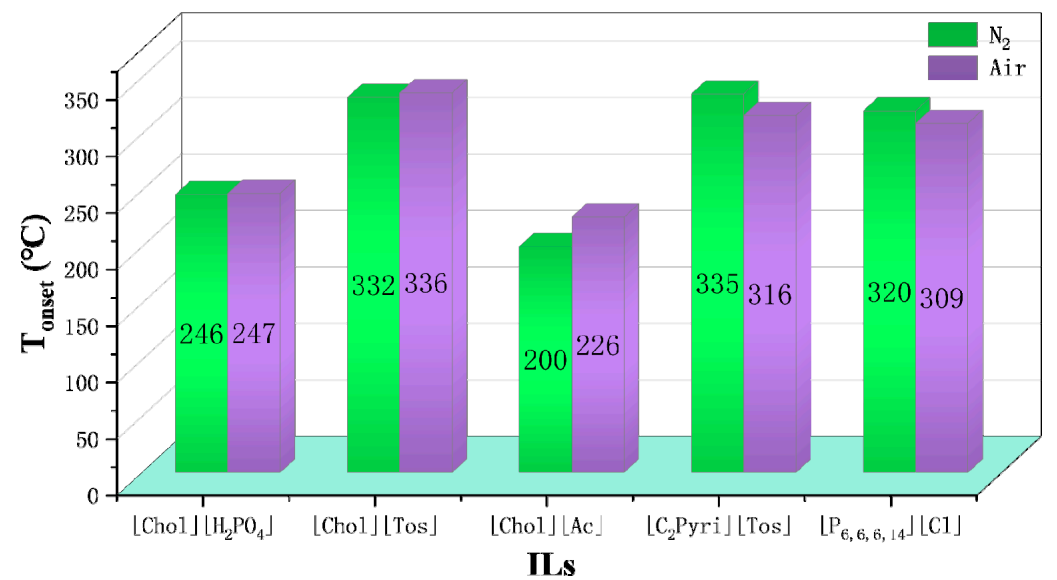

Figure 7. $\mathrm{T}_{\text {onset }}$ of choline, pyridinium, and phosphonium ILs in $\mathrm{N}_{2}$ and air at a heating rate of $10{ }^{\circ} \mathrm{C} / \mathrm{min}[40,73]$. Reproduced with permission from Clio Deferm, Physical Chemistry Chemical Physics; published by Royal Society of Chemistry, 2018; reproduced with permission from J.J.Parajó, The Journal of Chemical Thermodynamics; published by Elsevier, 2020.

\subsubsection{Impurities}

In most cases, water has a wide range of values from $30 \mathrm{ppm}$ to $21,000 \mathrm{ppm}[51,66,73]$. For different kinds of ILs, water has different effects on their thermal stability. On one hand, water hinders the degradation reaction of $\left[\mathrm{C}_{2} \mathrm{MIM}\right][\mathrm{Ac}]$ and $\left[\mathrm{C}_{4} \mathrm{MIM}\right][\mathrm{Ac}]$, as shown by Williams et al. that the mass of $\left[\mathrm{C}_{2} \mathrm{MIM}\right][\mathrm{Ac}]$ and $\left[\mathrm{C}_{4} \mathrm{MIM}\right][\mathrm{Ac}]$ decreased significantly in an isothermal TGA at $150{ }^{\circ} \mathrm{C}$, but the time-lapsed changed in the UV-vis spectra monitored over $24 \mathrm{~h}$ showed that mixtures of $\left[\mathrm{C}_{2} \mathrm{MIM}\right][\mathrm{Ac}]$ and $\left[\mathrm{C}_{4} \mathrm{MIM}\right][\mathrm{Ac}]$ with water did not display any significant decomposition at $150^{\circ} \mathrm{C}$ [36]. The observed results are in line with the research of $\left[\mathrm{C}_{2} \mathrm{MIM}\right][\mathrm{AcO}]$ and $\left[\mathrm{C}_{4} \mathrm{MIM}\right][\mathrm{AcO}]$ [82]. On the other hand, the $\mathrm{T}_{\text {onset }}$ of the quaternary phosphonium carboxylate ILs decreases by $19.8^{\circ} \mathrm{C}$ at most when the water content is saturated, as shown in Figure 8 [83]. Moreover, the TGA curves of two protic ILs, [DEMA] $\left[\mathrm{HSO}_{4}\right]$ and [DEMA] $\left[\mathrm{CF}_{3} \mathrm{COO}\right.$ ], decrease markedly with the increase of water content [84]. However, for $\left[\mathrm{C}_{1} \mathrm{OC}_{2} \mathrm{C}_{1} \mathrm{Py}\right]\left[\mathrm{NTf}_{2}\right],\left[\mathrm{C}_{1} \mathrm{OC}_{2} \mathrm{C}_{1} \mathrm{Py}\right]\left[\left(\mathrm{C}_{2} \mathrm{~F}_{5}\right)_{3} \mathrm{PF}_{3}\right]$, and $\left[\mathrm{P}_{6,6,6,14}\right]\left[\left(\mathrm{C}_{2} \mathrm{~F}_{5}\right)_{3} \mathrm{PF}_{3}\right]$, differences of $\mathrm{T}_{\text {onset }}$ between water saturation and supply conditions are lower than the expanded uncertainties of the apparatus [63].

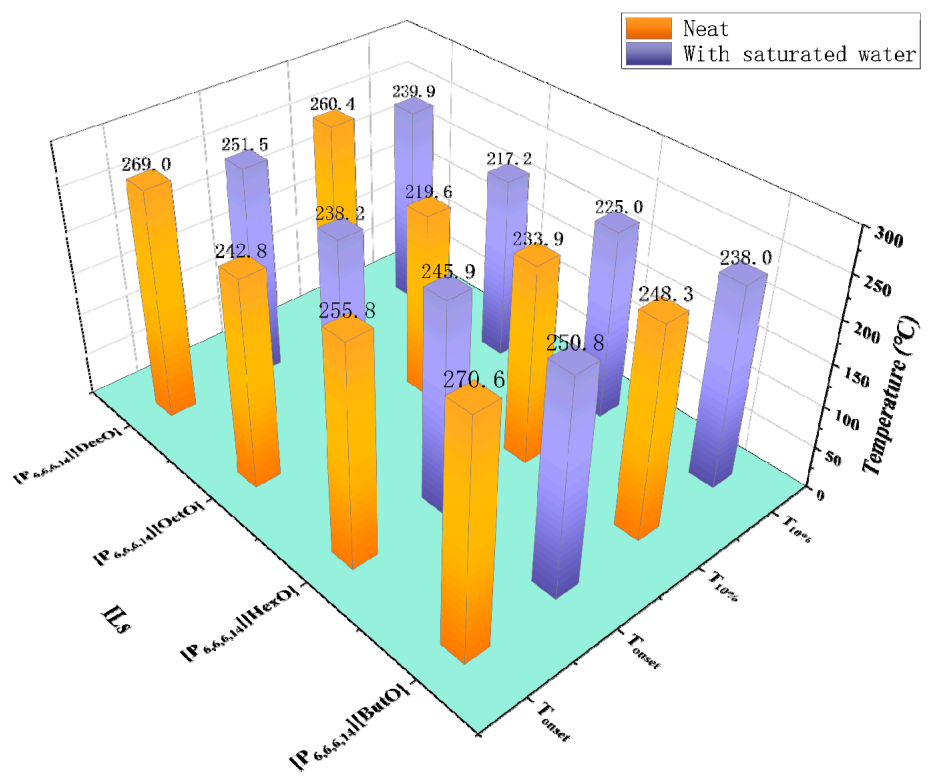

Figure 8. $\mathrm{T}_{\text {onset }}$ and $\mathrm{T}_{10 \%}$ of neat ILs and mixtures with water at a heating rate of $5{ }^{\circ} \mathrm{C} / \mathrm{min}$ in nitrogen atmosphere [83]. 
In addition to water, the influence of inorganic salts and metal oxides on thermal stability has also been studied. Adding $\mathrm{CuO}$ to $\left[\mathrm{C}_{2} \mathrm{MIM}\right][\mathrm{Ac}]$ results in an exothermic reaction and lowers the decomposition temperature. It is assumed that $\mathrm{CuO}$ decomposes ester compounds produced from $\left[\mathrm{C}_{2} \mathrm{MIM}\right][\mathrm{Ac}]$ as it might accelerate the decomposition of organic compounds [85]. In addition, results summarized in Figure 9 show $\mathrm{T}_{\text {onset }}$ of bulk ILs are significantly higher than the $\mathrm{T}_{\text {onset }}$ of $\gamma-\mathrm{Al}_{2} \mathrm{O}_{3}$-supported ILs, indicating the interactions of ILs with $\gamma-\mathrm{Al}_{2} \mathrm{O}_{3}$ control their thermal stability limits [58]. Putting 20\% $\mathrm{NH}_{4} \mathrm{Cl}$ into [BMMIM][Cl] reduces the thermal stability [86], and $\mathrm{T}_{\text {onset }}$ of commercial $\left[\mathrm{P}_{6,6,6,14}\right][\mathrm{Cl}]$ is $8{ }^{\circ} \mathrm{C}$ lower than its pure counterpart [40]. Both studies mean the existence of impurities alters the thermal stability of ILs.

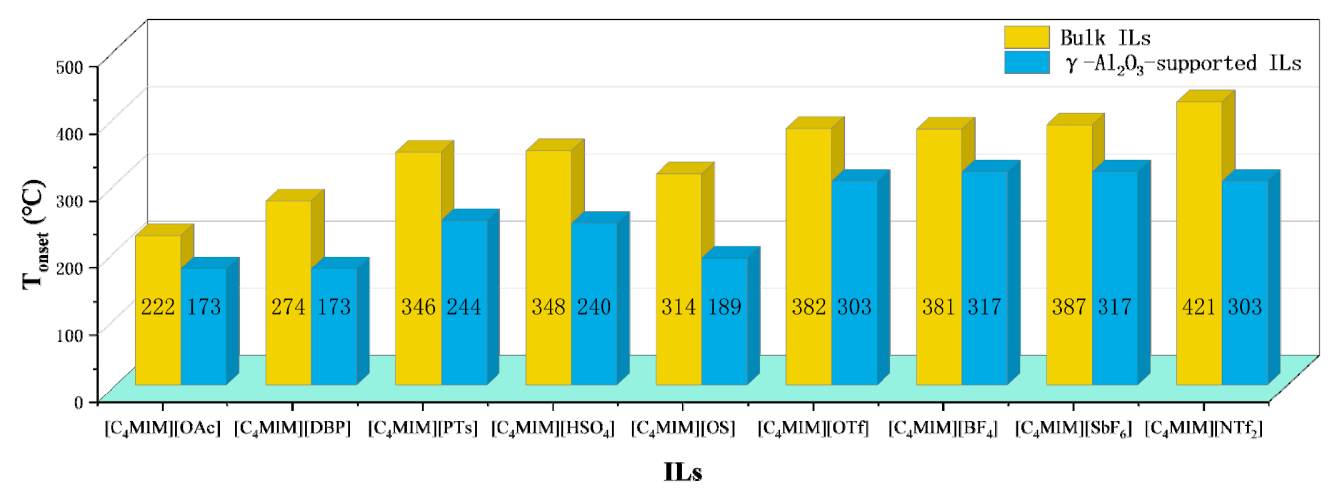

Figure 9. $\mathrm{T}_{\text {onset }}$ of Bulk and $\gamma-\mathrm{Al}_{2} \mathrm{O}_{3}$-supported ILs at a heating rate of $10{ }^{\circ} \mathrm{C} / \mathrm{min}$ in nitrogen atmosphere [58].

\section{Kinetics of Thermal Decomposition}

The kinetic data in the thermal decomposition process can be obtained based on isothermal and non-isothermal TGAs. Generally, the rate of thermal decomposition can be expressed by the following formula:

$$
\begin{gathered}
d \alpha / d t=k(T) \cdot f(\alpha) \\
\alpha=\frac{m_{0}-m}{m_{0}-m_{1}}
\end{gathered}
$$

where $k(T)$ is the rate constant, $f(\alpha)$ is determined by the kinetic models as shown in Table 1 , and $m_{0}, m$, and $m_{1}$ are the initial mass, mass at certain time, and terminal mass of the sample, respectively. $\alpha$ is defined as the fraction of the total mass loss in the process, ranging from 0 (no mass loss) to 1 (complete mass loss).

Table 1. Some of the models used in thermal decomposition kinetics of ILs. $(n \neq 1)$.

\begin{tabular}{ccc}
\hline Reaction Model & Code & $\mathbf{f}(\boldsymbol{\alpha})$ \\
\hline Power law & P2 & $2 \alpha^{1 / 2}$ \\
Power law & P3 & $3 \alpha^{2 / 3}$ \\
One-dimensional diffusion & D1 & $1 / 2 \alpha^{-1}$ \\
Two-dimensional diffusion & D2 & {$[-\ln (1-\alpha)]^{-1}$} \\
Three-dimensional diffusion & D3 & 1 \\
Zero-order & F0 & $1-\alpha / 2(1-\alpha)^{2 / 3}\left[1-(1-\alpha)^{1 / 3}\right]^{-1}$ \\
First-order & F1 & $(1-\alpha)^{\mathrm{n}}$ \\
nth order & Fn
\end{tabular}

The correlation between the rate constant and the temperature is defined by the Arrhenius equation as

$$
k(T)=A \cdot \exp \left(-\frac{E}{R T}\right)
$$


where $A$ denotes the pre-exponential factor, $E$ is the activation energy, $R$ is the universal gas constant, and $T$ refers to the temperature.

Combining Equation (4) and Equation (6) yields

$$
d \alpha / d t=A \cdot \exp \left(-\frac{E}{R T}\right) \cdot f(\alpha) .
$$

If the heating rate $\beta$ is constant, then Equation (7) can be transformed into Equation (8) as follows:

$$
\beta(d \alpha / d t)=A \cdot \exp \left(-\frac{E}{R T}\right) \cdot f(\alpha)
$$

The calculation of Arrhenius parameters, $E$ and $A$, will be introduced in the following sections.

\subsection{Isoconversional Methods}

The isoconversional methods are based on the isoconversional principle, meaning that the reaction rate $d \alpha / d t$ is only a function of temperature at a constant extent of conversion [41] and the reaction model $f(\alpha)$ is independent of temperature [87]. In addition, these methods require that the decomposition process can be approximated as a single-step kinetic process, that is to say, activation energy calculated by isoconversional methods does not vary significantly with $\alpha$ [88]. According to this principle, the isoconversional values of activation energy $E_{\alpha}$ can be evaluated without assuming or determining any particular form of the reaction model, so the isoconversional methods are frequently called "model-free" methods. Currently, these methods have been classified into differential isoconversional methods and integral isoconversional methods.

\subsubsection{Differential Isoconversional Methods}

Taking the logarithm on both sides of Equation (8), the most representative differential isoconversional method is obtained according to Friedman [89]

$$
\ln \left[\beta_{i}(d \alpha / d t)_{\alpha, i}\right]=\ln \left[f(\alpha) A_{\alpha}\right]-\frac{E_{\alpha}}{R T_{\alpha, i}}
$$

where the subscript $i$ denotes individual heating rate, and $T_{\alpha, i}$ is the temperature at which the extent of conversion $\alpha$ is reached under $i$ th heating rate. The activation energy corresponding to each conversion $\alpha$ can be obtained easily by using DTG and TGA data. As shown in Figure 10, in order to better characterize the thermal decomposition process of $\left[\mathrm{C}_{4} \mathrm{MIM}\right]\left[\mathrm{PF}_{6}\right]$ in the nitrogen atmosphere, the thermal decomposition is divided into two steps. The activation energy value calculated by the Friedman method suggests that the linearity of the result is relatively poor in the fitting process and the activation energy varies significantly with $\alpha$ [55]. In addition, a similar conclusion has also been drawn in other investigations [90]. In the non-isothermal kinetic analysis of imidazolium [NTf 2 ] ILs, it is found that the activation energy calculated by the Friedman method has the largest variation range [44]. 

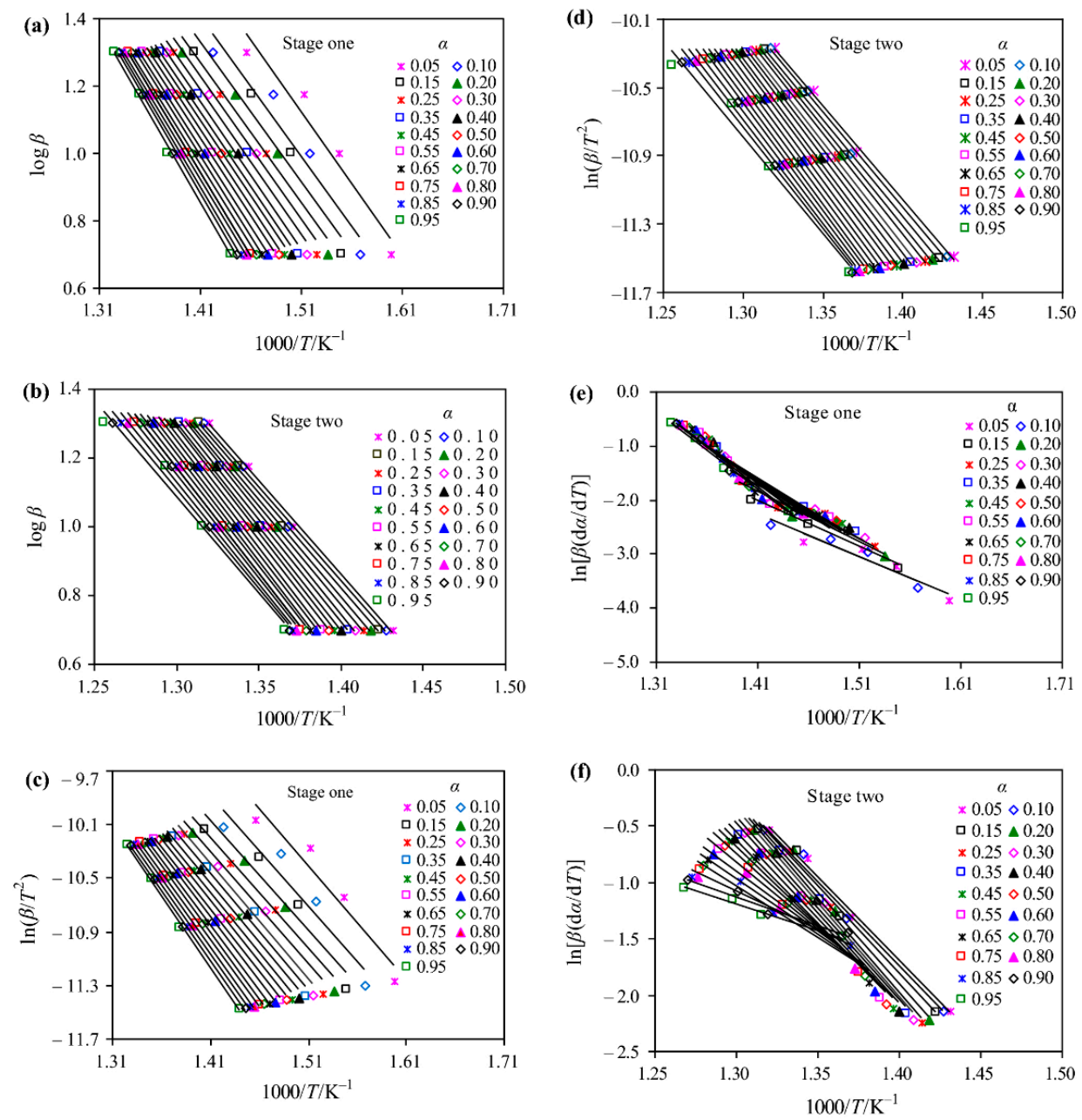

Figure 10. Linear Arrhenius plots for $\left[\mathrm{C}_{4} \mathrm{MIM}\right]\left[\mathrm{PF}_{6}\right]$ in a nitrogen atmosphere.(a), (b) Flynn-WallOzawa (FWO) method $\log \beta$ versus $1000 / T$; (c), (d) Coats-Redfern (CR) method $\ln \left(\beta / T^{2}\right.$ ) versus 1000/T and; (e), (f) Friedman method $\ln [\beta(\mathrm{d} \alpha / \mathrm{d} t)]$ versus 1000/T [55]. Reproduced with permission from Zhen Huang, Journal of Thermal Analysis and Calorimetry; published by Springer Nature, 2019.

\subsubsection{Integral Isoconversional Methods}

By integrating Equation (7), the following equation can be obtained as

$$
\mathrm{g}(\alpha) \equiv \int_{0}^{\alpha} \frac{d \alpha}{f(\alpha)}=A \cdot \int_{0}^{t} \exp \left(-\frac{E}{R T}\right) d t
$$

In the case of constant heating rate, Equation (10) can be converted into

$$
\mathrm{g}(\alpha) \equiv \int_{0}^{T_{\alpha}} \frac{d \alpha}{f(\alpha)}=\frac{A}{\beta} \cdot \int_{0}^{T} \exp \left(-\frac{E}{R T}\right) d T
$$

According to the isoconversional principle, Equation (10) can be converted into Equation (12) under the isothermal condition as follows:

$$
\operatorname{lnt}_{\alpha, i}=\ln \left[g(\alpha) / A_{\alpha}\right]+\frac{E_{\alpha}}{R T_{i}}
$$

where $T_{i}$ indicates isothermal temperature, and $\mathbf{t}_{\alpha, i}$ is the time to reach a given extent of conversion in the $i$ th isothermal experiment. Apart from the study by Williams et al. that used this method to calculate the activation energy and pre-exponential factor values of 
1-alkyl-3-methylimidazolium chloride ILs [57], no other literature is known using this method to analyze the thermal degradation kinetics of ILs.

Compared with isothermal experiments, the constant heating rate ( $\beta=$ constant) is more popular in isoconversional kinetic analysis $[18,39,49,53,56,57]$. There is no analytical solution to the integral of Equation (11), so a series of integral isoconversional methods using different approximations have appeared. Many integral isoconversional methods can be expressed in the following form [91]:

$$
\ln \left(\beta_{i} / T_{\alpha, i}^{B}\right)=\text { Const }-C \frac{E_{\alpha}}{R T_{\alpha}}
$$

Flynn-Wall-Ozawa (FWO) method [92,93], Kissinger-Akahira-Sunose (KAS) [94] method, which is also known as Coats-Redfern (CR) method [95], and Starink method [96] are all derived based on Equations (14)-(16), respectively. Then the activation energy values can be calculated from the slope of plots.

$$
\begin{gathered}
\ln \left(\beta_{i}\right)=\text { Const }-1.052 \frac{E_{\alpha}}{R T_{\alpha}} \\
\ln \left(\beta_{i} / T_{\alpha, i}^{2}\right)=\text { Const }-\frac{E_{\alpha}}{R T_{\alpha}} \\
\ln \left(\beta_{i} / T_{\alpha, i}^{1.92}\right)=\text { Const }-1.0008 \frac{E_{\alpha}}{R T_{\alpha}}
\end{gathered}
$$

Table 2 indicates that the activation energy difference of $\left[\mathrm{C}_{4} \mathrm{MIM}\right]\left[\mathrm{NTf}_{2}\right]$ calculated by the KAS method, FWO method, and Starink method is less than $5.4 \mathrm{~kJ} / \mathrm{mol}$, and the correlation coefficients $\left(R^{2}\right)$ is all greater than 0.97 [18]. The calculated results are in line with many other studies $[44,53,54]$. Therefore, as recommended by ICTAC (the International Confederation for Thermal Analysis and Calorimetry), there is no need to perform kinetic

\begin{tabular}{|c|c|c|c|c|c|c|c|}
\hline & \multirow{2}{*}{$\alpha$} & \multicolumn{2}{|l|}{ KAS } & \multicolumn{2}{|l|}{ FWO } & \multicolumn{2}{|c|}{ Starink } \\
\hline & & $E_{\alpha} / \mathrm{kJ} \mathrm{mol}^{-1}$ & $\mathbf{R}^{2}$ & $E_{\alpha} / \mathrm{kJ} \mathrm{mol}^{-1}$ & $\mathbf{R}^{2}$ & $E_{\alpha} / \mathrm{kJ} \mathrm{mol}^{-1}$ & $\mathbf{R}^{2}$ \\
\hline & 0.1 & 109.5 & 0.99 & 114.6 & 0.99 & 109.9 & 0.99 \\
\hline & 0.2 & 116.9 & 0.99 & 121.9 & 0.99 & 117.3 & 0.99 \\
\hline & 0.3 & 121.6 & 0.99 & 126.5 & 0.99 & 122.0 & 0.99 \\
\hline & 0.4 & 121.3 & 0.99 & 126.4 & 0.99 & 121.7 & 0.99 \\
\hline & 0.5 & 120.3 & 0.99 & 125.6 & 0.99 & 120.7 & 0.99 \\
\hline & 0.6 & 116.7 & 0.99 & 122.2 & 0.99 & 117.1 & 0.99 \\
\hline & 0.7 & 112.2 & 0.97 & 118.0 & 0.98 & 112.6 & 0.97 \\
\hline & 0.8 & 108.8 & 0.97 & 114.9 & 0.97 & 109.2 & 0.97 \\
\hline Average & & 115.9 & & 121.3 & & 116.3 & \\
\hline
\end{tabular}
analysis in multiple forms of integral isoconversional methods [88].

Table 2. Correlation coefficient and activation energy for the $\left[\mathrm{C}_{4} \mathrm{MIM}\right]\left[\mathrm{NTf}_{2}\right]$ calculated using different integral isoconversional methods [18].

The numerical integration developed by Vyazovkin et al. improves the calculation accuracy [97-99]. For a series of different heating rates, the activation energy values can be obtained by minimizing the following function:

$$
\phi\left(E_{\alpha}\right)=\sum_{i=1}^{n} \sum_{j \neq i}^{n} \frac{I\left(E_{\alpha}, T_{\alpha, i}\right) \beta_{j}}{I\left(E_{\alpha}, T_{\alpha, j}\right) \beta_{i}}
$$


where the subscript $i$ denotes different heating programs, and the subscript $j$ is used to denote all heating rates other than $i$. In order to reduce error as much as possible, the temperature integral is calculated over a small segment [87] as

$$
I\left(E_{\alpha}, T_{\alpha, i}\right)=\int_{T_{\alpha-\Delta \alpha}}^{T_{\alpha}} \exp \left(\frac{-E_{\alpha}}{R T}\right) d t
$$

Table 3 shows that the activation energy values calculated by the Vyazovkin method are similar to the results of the KAS and Starink methods, indicating that the latter two simple integration methods are precise enough in most cases [55,57], and the Vyazovkin method is a better choice when the activation energy values vary with $\alpha$ obviously [88].

Table 3. The activation energy $\left(E_{\alpha}\right)$ values determined from the Kissinger-Akahira-Sunose (KAS) method, Vyazovkin method, Starink method, and max-rate Starink method. Reproduced with permission from Zhen Huang, Journal of Thermal Analysis and Calorimetry; published by Springer Nature, 2019; reproduced with permission from Michael L.Williams, Thermochimica Acta; published by Elsevier, 2020.

\begin{tabular}{|c|c|c|}
\hline ILs & Method & $\mathrm{E} \alpha / \mathrm{kJ} \mathrm{mol}{ }^{-1}$ \\
\hline \multirow{4}{*}[\mathrm{C}_{4}\mathrm{MIM}]{$\left[\mathrm{PF}_{6}\right][55]$} & \multirow{2}{*}{ Vyazovkin } & 77.52 \\
\hline & & 101.22 \\
\hline & \multirow{2}{*}{ KAS } & 76.83 \\
\hline & & 100.60 \\
\hline \multirow{2}{*}[\mathrm{C}_{2}\mathrm{MIM}]{$[\mathrm{Cl}][57]$} & Vyazovkin & 120.8 \\
\hline & Starink & 121.6 \\
\hline \multirow{2}{*}[\mathrm{C}_{3}\mathrm{MIM}]{$[\mathrm{Cl}][57]$} & Vyazovkin & 151.5 \\
\hline & Starink & 155.0 \\
\hline \multirow{2}{*}[\mathrm{C}_{4}\mathrm{MIM}]{$[\mathrm{Cl}][57]$} & Vyazovkin & 146.8 \\
\hline & Starink & 150.8 \\
\hline \multirow{2}{*}[\mathrm{C}_{6}\mathrm{MIM}]{$[\mathrm{Cl}][57]$} & Vyazovkin & 98.6 \\
\hline & Starink & 97.9 \\
\hline \multirow{2}{*}[\mathrm{C}_{10}\mathrm{MIM}]{$[\mathrm{Cl}]$ [57] } & Vyazovkin & 148.2 \\
\hline & Starink & 149.7 \\
\hline
\end{tabular}

\subsubsection{Maximum-Rate Methods}

When the maximum rate of decomposition of ILs is achieved, $T_{\alpha}$ in Equation (13) can be replaced by $T_{\text {peak }}$ [91]. This class of methods will be indicated by adding "max rate" before the name. In the max-rate Starink method, the activation energy of 1-alkyl-3methylimidazolium chloride can be calculated, which is similar to that calculated by the Vyazovkin method and Starink method, as shown in Table 4 [57]. However, the activation energy of $\left[\mathrm{C}_{4} \mathrm{MPy}\right]\left[\mathrm{NTf}_{2}\right]$ calculated by $T_{\text {peak }}$ is about $20 \mathrm{~kJ} / \mathrm{mol}$ higher than that calculated by $T_{\alpha}[53]$. 
Table 4. The activation energy values determined from the integral isoconversional methods and maximum-rate methods. Reproduced with permission from Khurrum Shehzad Quraishi, Journal of Thermal Analysis and Calorimetry; published by Springer Nature, 2017; reproduced with permission from Michael L.Williams, Thermochimica Acta; published by Elsevier, 2020.

\begin{tabular}{|c|c|c|}
\hline ILs & Method & $\mathrm{E} \alpha / \mathrm{kJ} \mathrm{mol}^{-1}$ \\
\hline \multirow{2}{*}[\mathrm{C}_{2}\mathrm{MIM}]{$[\mathrm{Cl}][57]$} & Starink & 121.6 \\
\hline & Max-rate Starink & 114.6 \\
\hline \multirow{2}{*}[\mathrm{C}_{3}\mathrm{MIM}]{$[\mathrm{Cl}][57]$} & Starink & 155.0 \\
\hline & Max-rate Starink & 155.6 \\
\hline \multirow{2}{*}[\mathrm{C}_{4}\mathrm{MIM}]{$[\mathrm{Cl}]$ [57] } & Starink & 150.8 \\
\hline & Max-rate Starink & 136.6 \\
\hline \multirow{2}{*}[\mathrm{C}_{6}\mathrm{MIM}]{$[\mathrm{Cl}][57]$} & Starink & 97.9 \\
\hline & Max-rate Starink & 96.1 \\
\hline \multirow{2}{*}[\mathrm{C}_{10}\mathrm{MIM}]{$[\mathrm{Cl}][57]$} & Starink & 149.7 \\
\hline & Max-rate Starink & 139.9 \\
\hline \multirow{6}{*}[\mathrm{C}_{4}\mathrm{MPy}]{$\left[\mathrm{NTf}_{2}\right][53]$} & FWO & 128.6 \\
\hline & Max-rate FWO & 149.20 \\
\hline & KAS & 123.6 \\
\hline & Max-rate KAS & 144.97 \\
\hline & Starink & 124.0 \\
\hline & Max-rate Starink & 144.30 \\
\hline
\end{tabular}

\subsection{Arrhenius Methods}

According to the data of isothermal TGA, Arrhenius methods directly use Equation (6) to calculate the values of activation energy and pre-exponential factor. Due to the simplicity of the calculation process, Arrhenius methods have been used extensively $[39,44,71,100,101]$. By assuming the decomposition is of zero-order or first-order, the rate constant $k(T)$ can be calculated.

For zero-order reactions

$$
k(T)=-d m / d t
$$

Equation (19) can be transformed into

$$
\ln (-d m / d t)=\ln (A)-\frac{E}{R T}
$$

where $m$ is sample mass, and $d m / d t$ is obtained as the slope of a linear fitting of mass loss versus time for every isothermal TGA. The activation energy and pre-exponential factor can be derived from Equation (20). Several studies have applied this method to calculate the activation energy and pre-exponential factor $[47,74,75,78,101]$. As shown in Table 5, Parajó et al. used both the isoconversional methods and the zero-order Arrhenius method to calculate the activation energies of several imidazolium $\left[\mathrm{NTf}_{2}\right]$ ILs, and they found some activation energies calculated by the non-isothermal methods are about $20 \mathrm{~kJ} / \mathrm{mol}$ lower than those calculated by the isothermal method [44]. 
Table 5. Activation energies for the selected ILs by the different methods in the air atmosphere [44].

\begin{tabular}{|c|c|c|c|c|}
\hline \multirow[t]{3}{*}{ ILs } & \multicolumn{4}{|c|}{$\mathrm{E} / \mathrm{kJ} \mathrm{mol}^{-1}$} \\
\hline & \multicolumn{3}{|c|}{ Non-Isothermal Methods } & \multirow{2}{*}{$\begin{array}{c}\text { Isothermal Method } \\
\text { Zero-Order } \\
\text { Arrhenius Method }\end{array}$} \\
\hline & Friedman & KAS & FWO & \\
\hline$\left[\mathrm{C}_{2} \mathrm{MIM}\right]\left[\mathrm{NTf}_{2}\right]$ & $102 \pm 5$ & $102 \pm 7$ & $108 \pm 6$ & $122 \pm 11$ \\
\hline$\left[\mathrm{C}_{3} \mathrm{MIM}\right]\left[\mathrm{NTf}_{2}\right]$ & $100 \pm 7$ & $92 \pm 7$ & $98 \pm 7$ & $125 \pm 8$ \\
\hline$\left[\mathrm{C}_{4} \mathrm{MIM}\right]\left[\mathrm{NTf}_{2}\right]$ & $130 \pm 6$ & $125 \pm 5$ & $130 \pm 5$ & $144 \pm 8$ \\
\hline$\left[\mathrm{C}_{4} \mathrm{MMIM}\right]\left[\mathrm{NTf}_{2}\right]$ & $118 \pm 11$ & $119 \pm 13$ & $124 \pm 12$ & $129 \pm 5$ \\
\hline
\end{tabular}

For the first-order reaction

$$
k(T) \cdot m=-d m / d t
$$

Equation (21) can be transformed into

$$
\ln (-d m / d t)=\ln (A)-\frac{E}{R T}+\ln (m)
$$

Table 6 shows the values of activation energy and pre-exponential factor calculated by the first-order Arrhenius method, and these values are quite different from other calculation results. In the studies of Efimova et al., the activation energy values are calculated using the isoconversional methods, and then Equation (22) is used to calculate the pre-exponential factor values $[39,71]$.

Table 6. Activation energy and pre-exponential factor calculated by the first-order Arrhenius method, zero-order Arrhenius method, and KAS method. Reproduced with permission from Wenlong Wang, Chemical Engineering Journal; published by Elsevier, 2017; reproduced with permission from Juan J. Parajó, The Journal of Chemical Thermodynamics; published by Elsevier, 2017; reproduced with permission from Yuanyuan Cao, Industrial \& Engineering Chemistry Research; published by American Chemical Society, 2014; reproduced with permission from Florian Heym, Chemie Ingenieur Technik; published by Wiley, 2015.

\begin{tabular}{ccccc}
\hline ILs & $\mathbf{E / \mathbf { k J ~ m o l } ^ { - \mathbf { 1 } }}$ & $\mathbf{A} / \mathbf{m i n}^{-\mathbf{1}}$ & Method & Reference \\
\hline$\left[\mathrm{C}_{2} \mathrm{MIM}\right]\left[\mathrm{NTf}_{2}\right]$ & 317 & $7.2 \times 10^{21}$ & First-order Arrhenius method & {$[100]$} \\
& 131.6 & $1.716 \times 10^{11}$ & Zero-order Arrhenius method & {$[74]$} \\
& 102 & - & KAS method & {$[44]$} \\
{$\left[\mathrm{C}_{4} \mathrm{MIM}\right]\left[\mathrm{NTf}_{2}\right]$} & 287 & $7.2 \times 10^{19}$ & First-order Arrhenius method & {$[100]$} \\
& 126.4 & $3.047 \times 10^{10}$ & Zero-order Arrhenius method & {$[74]$} \\
& 115.9 & - & KAS method & {$[18]$} \\
\hline
\end{tabular}

\subsection{Determining the Pre-Exponential Factor}

Despite the isoconversional methods are convenient to calculate the values of activation energy without the reaction model, it is difficult to obtain the values of the preexponential factor. For single-step reactions, the pre-exponential factors can be determined by the following means when using model-free methods [88].

\subsubsection{Using Compensation Effect}

Different pairs of the Arrhenius parameters $A_{k}$ and $E_{k}$ can be obtained by substituting different $f(\alpha)$ and experimental data into Equation (8). Although the Arrhenius parameters vary widely with $f(\alpha)$, according to the compensation effect, they conform to the following correlation [88]:

$$
\ln A_{k}=a E_{k}+b
$$


where $a$ and $b$ are the parameters of the compensation effect and are determined by fitting the pairs of $\ln A_{k}$ and $E_{k}$ at different $\alpha$ into Equation (23). Then for the single-step reaction, the average pre-exponential factor $A_{0}$ can be obtained by substituting the average activation energy $E_{0}$ determined in non-isothermal experiments into Equation (23). Using the compensation effect, Haung et al. and Jiang et al. calculated the pre-exponential factors of $\left[\mathrm{C}_{4} \mathrm{MIM}\right]\left[\mathrm{PF}_{6}\right]$ and $\left[\mathrm{C}_{4} \mathrm{MIM}\right][\mathrm{DBP}]$, respectively $[55,56]$. The pre-exponential factors of $\left[\mathrm{C}_{4} \mathrm{MIM}\right]\left[\mathrm{PF}_{6}\right]$ ranged from $9.28 \times 10^{3}$ to $3.89 \times 10^{8} \mathrm{~min}^{-1}$, while those calculated by the Arrhenius method are $2.6686 \times 10^{11} \mathrm{~min}^{-1}$ [74].

\subsubsection{Using Master Plots}

Using a non-isothermal TGA, after determining the activation energy values of the reaction, the reaction mechanism can be simply and accurately determined by plotting master plots $z(\alpha)$ or $y(\alpha)[102,103]$. The $y(\alpha)$ function has the following form:

$$
y(\alpha)=(d \alpha / d t)_{\alpha} \exp \left(\frac{E_{0}}{R T_{\alpha}}\right)=A f(\alpha)
$$

After determining $(d \alpha / d t)_{\alpha}$ and $T_{\alpha}$ at different $\alpha$, it is possible to plot the experimental values of $y(\alpha)$ against $\alpha$. Because $A$ is an unknown constant, the shape of the theoretical master plots $y(\alpha)$ is the same as $f(\alpha)$. The experimental master plots $y(\alpha)$ are normalized to vary from 0 to 1 , then compared with the theoretical shape of $f(\alpha)$ in different kinetic models in Table 1, and the reaction model of thermal decomposition can be determined. Finally, $A$ can be easily obtained from Equation (24).

Another function $z(\alpha)$ has the following form:

$$
z(\alpha)=f(\alpha) g(\alpha)
$$

The temperature integral in $g(\alpha)$ can be approximately expressed by the following formula [97]:

$$
\begin{gathered}
g(\alpha)=\frac{A E}{\beta R} \exp (-x)[\pi(x) / x] \\
x=\frac{E_{\alpha}}{R T_{\alpha}} .
\end{gathered}
$$

where

$$
\pi(x)=\frac{x^{3}+x^{2}+88 x+96}{x^{4}+20 x^{3}+120 x^{2}+240 x+120}
$$

Combining Equations (7) and (26) followed by some rearrangement, the following equation is obtained:

$$
z(\alpha)=f(\alpha) g(\alpha)=(d \alpha / d t)_{\alpha} T_{\alpha}^{2}\left[\frac{\pi(x)}{\beta T_{\alpha}}\right]
$$

where $(d \alpha / d t)_{\alpha} T_{\alpha}^{2}\left[\frac{\pi(x)}{\beta T_{\alpha}}\right]$ is an experimental value. It has been proved $\left[\frac{\pi(x)}{\beta T_{\alpha}}\right]$ has a negligible influence on the shape of experimental master plots $z(\alpha)[102,103]$. So the correlation between experimental $z(\alpha)$ and $\alpha$ can be determined from the data of non-isothermal TGA and DTG. Theoretical master plots $z(\alpha)$ can be drawn according to different kinetic models in Table 1 , and the suitable reaction models can be determined by normalizing experimental $z(\alpha)$ and the theoretical ones in different kinetic models from 0 to 1 and comparing the normalized results.

After the reaction model has been established, Williams et al. calculated the preexponential factor values from Equation (24). By comparing the pre-exponential factor values of $\left[\mathrm{C}_{4} \mathrm{MIM}\right][\mathrm{Cl}]$ calculated by several different methods in Table 7 , it can be found that results calculated by master plots [57] are close to those calculated by the zero-order 
Arrhenius method [74], and those calculated by the first-order Arrhenius method [39] are much lower.

Table 7. Pre-exponential factor values of [BMIM][Cl] in different investigations. Reproduced with permission from Anastasia Efimova, The Journal of Physical Chemistry B; published by American Chemical Society, 2018; reproduced with permission from Michael L.Williams, Thermochimica Acta; published by Elsevier, 2020; reproduced with permission from Yuanyuan Cao, Industrial \& Engineering Chemistry Research; published by American Chemical Society, 2014.

\begin{tabular}{cccc}
\hline \multirow{2}{*}{ ILs } & \multicolumn{3}{c}{$\ln (\mathbf{A})^{*}$} \\
\cline { 2 - 4 } & Master Plots Method & $\begin{array}{c}\text { Zero-Order } \\
\text { Arrhenius Method }\end{array}$ & $\begin{array}{c}\text { First-Order } \\
\text { Arrhenius Method }\end{array}$ \\
\hline$\left[\mathrm{C}_{4} \mathrm{MIM}\right][\mathrm{Cl}]$ & $34.9[57]$ & $32.2[74]$ & $20.4[39]$ \\
\hline
\end{tabular}

${ }^{*} \mathrm{~A}$ is in $\mathrm{min}^{-1}$.

\section{Influence of Chemical Structure on Thermal Stability}

\subsection{Influence of Alkyl Chain Length}

As shown in Figure 11, a method based on the cations exchange of ILs with sodium montmorillonite clay (MMT-Na+) is adopted to estimate thermal stability from $\left[\mathrm{C}_{2} \mathrm{MIM}\right]^{+}$ to $\left[\mathrm{C}_{16} \mathrm{MIM}\right]^{+}$[104], and the $\mathrm{T}_{1 \%}$ and $\mathrm{T}_{50 \%}$ decrease with the increase of alkyl chain length. The same conclusion is obtained from quantum chemistry calculation [104]. The thermal stability of 1-alkyl-4-methyl-1,2,4-triazolium iodides shows a small but consistent decrease as the chain length is increased from butyl to dodecyl [105]. For the pyrrolidinium [ $\mathrm{NTf}_{2}$ ] ILs in Figure 12, although $\mathrm{T}_{\text {onset }}$ of $\left[\mathrm{C}_{8} \mathrm{MPy}\right]\left[\mathrm{NTf}_{2}\right]$ and $\left[\mathrm{C}_{9} \mathrm{MPy}\right]\left[\mathrm{NTf}_{2}\right]$ are higher than $\left[\mathrm{C}_{7} \mathrm{MPy}\right]\left[\mathrm{NTf}_{2}\right]$, it should be stressed that the longer chain length has resulted in lower thermal stability on the whole, and the difference of $\mathrm{T}_{\text {onset }}$ between $\left[\mathrm{C}_{3} \mathrm{MPy}\right]^{+}$and $\left[\mathrm{C}_{10} \mathrm{MPy}\right]^{+}$ is up to $48{ }^{\circ} \mathrm{C}$ [72]. Moreover, the thermal decomposition temperatures of [ $\mathrm{C}_{n} \mathrm{IMBS}\left[\mathrm{HSO}_{4}\right]$ generally decrease with the increase of chain length and the decomposition temperature decreases from 311 to $253^{\circ} \mathrm{C}$ when $n$ increases from 1 to 16 . This trend has also been observed in some studies of [ $\left.\mathrm{C}_{n} \mathrm{MIM}\right][\mathrm{Cl}]$ [57], [ $\left.\mathrm{N}_{8,8,8, n}\right][\mathrm{BScB}]$ [106], and [ $\left.\mathrm{PP}_{1 \mathrm{n}}\right]\left[\mathrm{NTf}_{2}\right]$ [107]. Generally, longer the chain length usually results in lower thermal stability, which is proved by more and more investigations $[46,53]$.

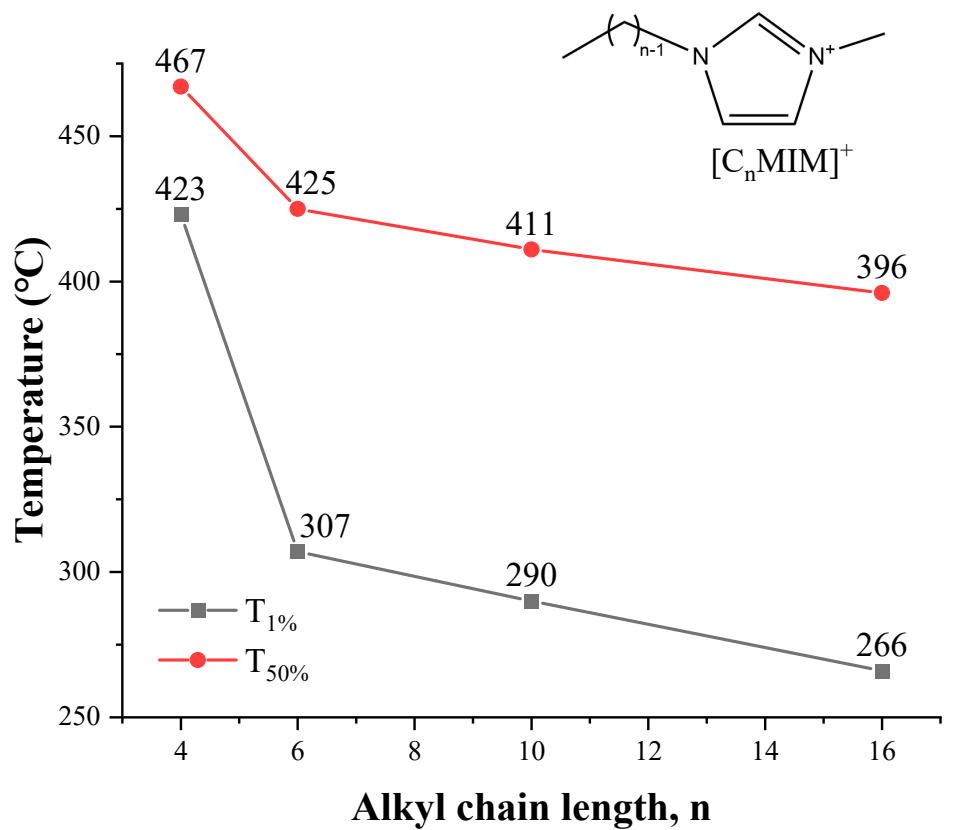

Figure 11. Thermal stability of MMT- $\left[\mathrm{C}_{\mathrm{n}} \mathrm{MIM}\right]^{+}$clays at a heating rate of $10{ }^{\circ} \mathrm{C} / \mathrm{min}$ in nitrogen atmosphere [104]. $(n=4,6,10,16)$ 


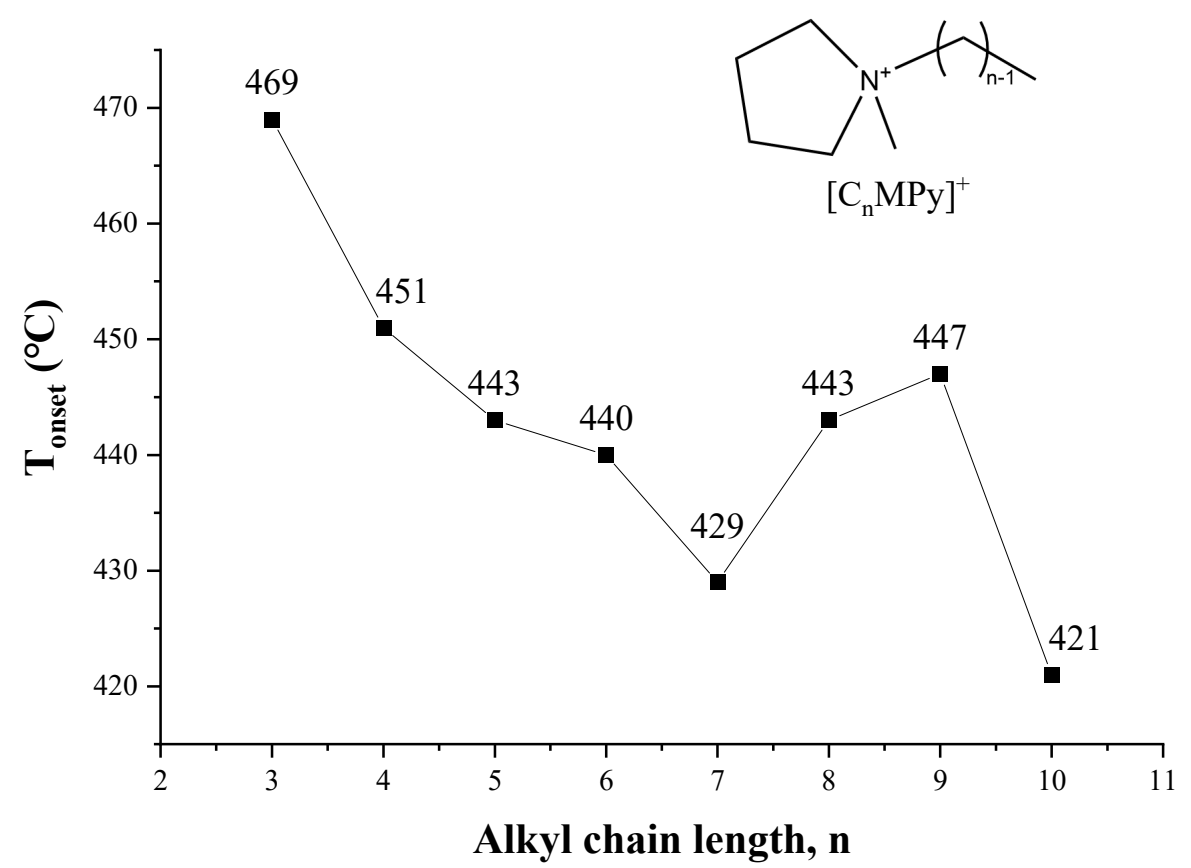

Figure 12. $\mathrm{T}_{\text {onset }}$ of $\left[\mathrm{C}_{\mathrm{n}} \mathrm{MPy}\right]\left[\mathrm{NTf}_{2}\right]$ at a heating rate of $10{ }^{\circ} \mathrm{C} / \mathrm{min}$ in nitrogen atmosphere [72]. ( $n=3-10)$ Reproduced with permission from Gebrekidan Gebresilassie Eshetu, ChemSusChem; published by Wiley, 2017.

However, there are some exceptions. Thermal stability of 1-alkyl-4-methyl-1,2,4triazolium [ $\mathrm{NTf}_{2}$ ] ILs in Figure 13 reveals that there is no correlation between $\mathrm{T}_{\text {onset }}$ and alkyl chain length, and $T_{0.01 / 10 \mathrm{~h}}$ instead increases with the increase of alkyl chain length [75]. The same results are obtained for some 3,5-dimethylpyrazolum ILs and some paramagnetic ILs $[108,109]$. In the study of amino acid ILs, [ $\left.\mathrm{N}_{1,1,14,2 \mathrm{O} 21}\right]$ [Lys] with the long-chain alkyl group on the side of nitrogen has higher thermal stability than $\left[\mathrm{N}_{1,1,6,2 \mathrm{O} 2 \mathrm{2}}\right][\mathrm{Lys}]$ under the isothermal condition, while both longer and shorter alkyl side chains harm the thermal stability under the non-isothermal condition [77].

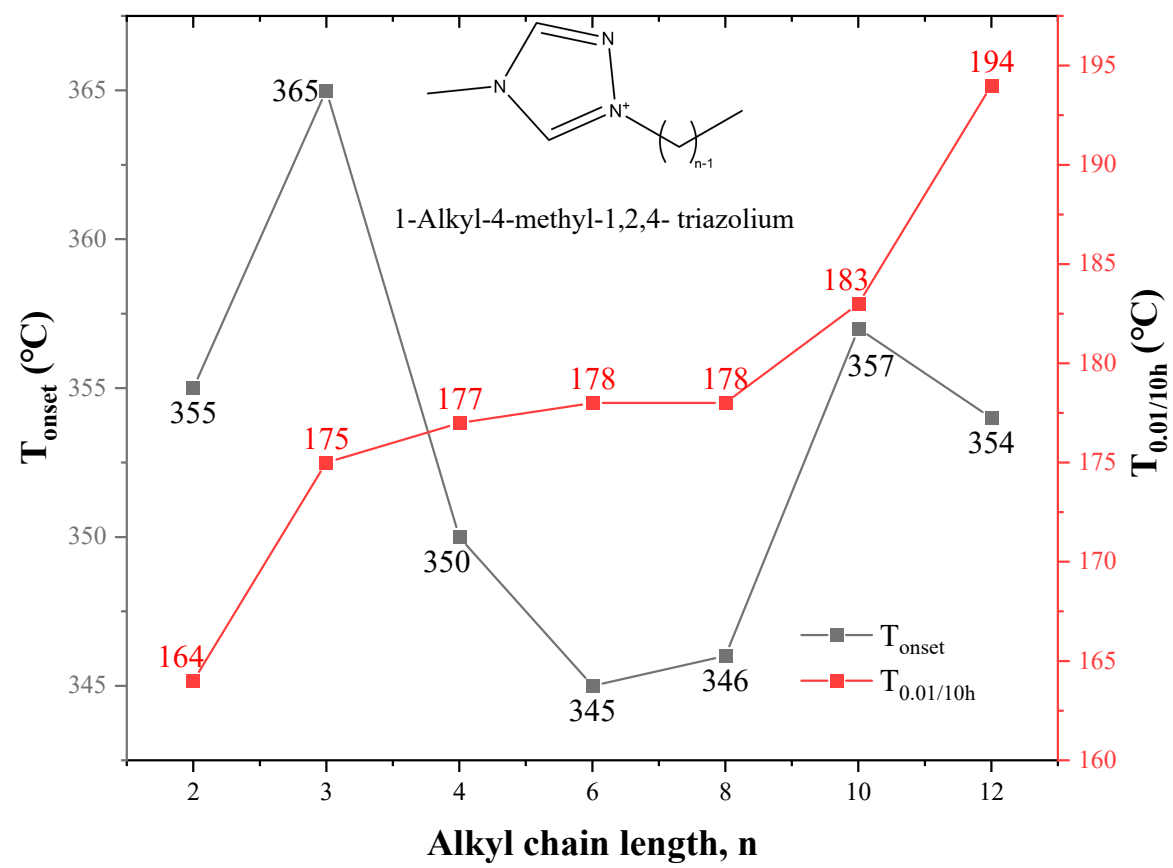

Figure 13. Thermal Properties of 1-alkyl-4-methyl-1,2,4-triazolium [ $\left.\mathrm{NTf}_{2}\right]$ ILs at a heating rate of $10{ }^{\circ} \mathrm{C} / \mathrm{min}$ in nitrogen atmosphere $[75](n=1,2,3,5,7,9,11)$. 
The influence of alkyl chain length on thermal stability can be explained as follows:

(1) Increasing the alkyl chain length weakens the bond between the alkyl chain and the cation such as imidazolium and ammonium, making it more vulnerable to attack and therefore more readily thermally decomposed $[53,106]$;

(2) Carbocations and carbon radicals with longer alkyl chains are more stable and easier to leave on heating, and thus ILs with longer alkyl chains favor the decomposition phenomenon [72];

(3) For choline based amino acid ILs, longer alkyl chains on cation create strong hydrophobic interaction with gradually decreased hydrogen bond interaction due to bulkier cationic size. Upon decreasing alkyl chain length, the reverse effect renders lowering the overall thermal stability of the ILs [77].

\subsection{Influence of Functionalization and Alkyl Substituents}

Comparing the decomposition temperature of some imidazolium ILs and amino acid ILs with different functional groups in Table 8, the functionalization usually decreases the thermal stability of ILs. $\left[\mathrm{C}_{2} \mathrm{MMIM}\right]\left[\mathrm{BF}_{4}\right]$ and $\left[\mathrm{C}_{2} \mathrm{MIM}\right][\mathrm{Br}]$ are more stable than $\left[\mathrm{C}_{2} \mathrm{NH}_{2} \mathrm{MMIM}\right]\left[\mathrm{BF}_{4}\right]$ and $\left[\mathrm{C}_{2} \mathrm{NH}_{2} \mathrm{MIM}\right][\mathrm{Br}]$ respectively. The reduced thermal stability is explained by the introduction of amine to the imidazolium cation, which makes the nearby carbon atom more positively charged and easier to be attacked by the anion [101]. Aromatic functionality also decreases the thermal stability of imidazolium [NTf $\left.{ }_{2}\right]$ ILs, and the $\mathrm{T}_{\text {onset }}$ of IL with two benzyls is higher than that with naphthylmethyl [110].

Hydroxyl functionalization has different effects on the thermal stability of ILs. The decomposition temperatures of $\left[\mathrm{C}_{n} \mathrm{OHMMIM}\right]\left[\mathrm{NTf}_{2}\right]$ are lower than $\left[\mathrm{C}_{n} \mathrm{MMIM}\right]\left[\mathrm{NTf}_{2}\right](n=2,3,4,6,8)$ and the maximum difference can reach $48^{\circ} \mathrm{C}$ [111]. Similarly, the substitution of the alkyl side chain to the hydroxyl group in $[\mathrm{EMIM}]\left[\mathrm{BF}_{4}\right]$ and $\left[\mathrm{C}_{2} \mathrm{MIM}\right]\left[\mathrm{C}_{4} \mathrm{~F}_{9} \mathrm{SO}_{3}\right]$ reduces their thermal stability $[74,112]$, which can be attributed to the higher chemical activity and easier decomposition of the hydroxyethyl group [61]. However, $\mathrm{T}_{\text {onset }}$ of $\left[\mathrm{C}_{3} \mathrm{OHMIM}\right][\mathrm{Cl}]\left(295^{\circ} \mathrm{C}\right)[113]$ are much higher than $\left[\mathrm{C}_{3} \mathrm{MIM}\right][\mathrm{Cl}]\left(246^{\circ} \mathrm{C}\right)[57]$, and hydroxyl functionalization also improves the thermal stability of [EMIM][Ac] and $\left[\mathrm{C}_{2} \mathrm{MIM}\right]\left[\mathrm{C}_{4} \mathrm{~F}_{9} \mathrm{CO}_{2}\right][74,112]$. It could be speculated that the hydrogen bonding interaction between the hydroxyethyl group and anion results in this trend, and the higher intramolecular hydrogen bond interaction stabilizes ILs and block thermal decomposition reaction to some extent [74].

Table 8. Thermal stability of ILs with different functional groups at a heating rate of $10^{\circ} \mathrm{C} / \mathrm{min}$ in an inert atmosphere.

\begin{tabular}{|c|c|c|c|}
\hline ILs & Structure of Cations & $\mathrm{T}_{\text {onset }} /{ }^{\circ} \mathrm{C}$ & Reference \\
\hline$\left[\mathrm{C}_{2} \mathrm{NH}_{2} \mathrm{MMIM}\right]\left[\mathrm{BF}_{4}\right]$ & & 284 & {$[101]$} \\
\hline$\left[\mathrm{C}_{2} \mathrm{MMIM}\right]\left[\mathrm{BF}_{4}\right]$ & & 391 & {$[101]$} \\
\hline$\left[\mathrm{C}_{2} \mathrm{NH}_{2} \mathrm{MIM}\right][\mathrm{Br}]$ & & 222 & [113] \\
\hline$\left[\mathrm{C}_{2} \mathrm{MIM}\right][\mathrm{Br}]$ & & 300 & [71] \\
\hline
\end{tabular}


Table 8. Cont.

ILs Structure of Cations

Moreover, ether in alkyl side chains is favorable for thermal decomposition. As the number of introduced ether increases, the thermal stability tends to decrease [66,114-116] because the introduction of oxygen atoms weakens the interaction between the cation and anion $[77,115]$. Specifically, Figure 14 demonstrates that the oxygen atom at the $\beta$-position significantly decreases the thermal stability of ILs, which can be explained by retro-alkylation of piperidinium ILs into 1-methyl piperidine and the corresponding oxocarbenium ion intermediates at elevated temperature [117]. In addition, the length of the O-alkyl chain also influences thermal stability. However, it is interesting that the increase of the length of the oxygen alkyl chain improves the thermal stability in isothermal TGA, while the conclusion obtained by non-isothermal TGA is opposite [77]. This contradiction between the results of non-isothermal TGA and isothermal TGA has also been found in other studies $[44,57,75,78,110]$.

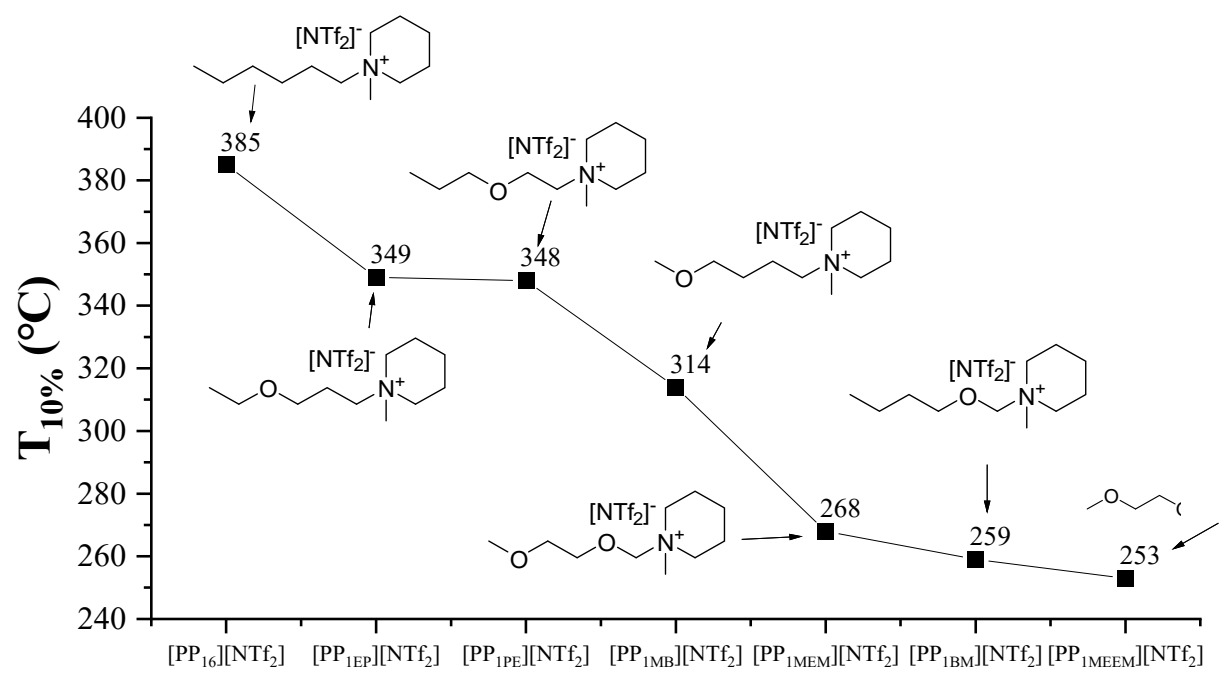

ILs

Figure 14. Thermal stability of piperidinium ILs with an oxygen atom-containing alkyl side chain at a heating rate of $10{ }^{\circ} \mathrm{C} / \mathrm{min}$ in argon atmosphere [117]. Reproduced with permission from T. Nokami, Faraday Discussions; published by Royal Society of Chemistry, 2018.

In addition to functional groups, the alkyl substituents also affect thermal stability. Ngo et al. [118] found that the thermal stability of the imidazolium ILs is improved by increasing the degree of substitution of hydrogen by alkyl groups on the imidazolium ring, the potential energy barrier for an attack is increased. Methyl substitution in $\mathrm{C}_{2}$ (the carbon atom between two nitrogen atoms in the imidazolium ring) enhances the 
thermal stability $[45,74,119]$. C-2H acidity of the imidazolium ring is one of the structural factors determining short-term thermal stability because the most acidic proton on the imidazolium cation locates at $C_{2}$ [58].

Moreover, Table 9 shows the bonding of the alkyl chain via tertiary carbon atom decreases the thermal stability of the IL, compared to those isomers, in which the alkyl is connected with the secondary carbon atom to the imidazolium ring $[66,120]$. The potential energy barrier of the decomposition reaction decreases because the decomposition products originating from tertiary carbon can be easily stabilized [66,72].

Table 9. $\mathrm{T}_{5 \%}$ of several isomeric and quasi-isomeric ILs at a heating rate of $10{ }^{\circ} \mathrm{C} / \mathrm{min}$ in argon atmosphere [66].

\begin{tabular}{|c|c|c|}
\hline ILs & Structure of Cations & $\mathrm{T}_{5 \%} /{ }^{\circ} \mathrm{C}$ \\
\hline [ethoxy $\left.\mathrm{C}_{5} \mathrm{IM}\right]\left[\mathrm{NTf}_{2}\right]$ & & 377.3 \\
\hline [ethoxyiC $\left.{ }_{5} \mathrm{IM}\right]\left[\mathrm{NTf}_{2}\right]$ & & 372.7 \\
\hline [ethoxyneoC $\left.{ }_{5} \mathrm{IM}\right]\left[\mathrm{NTf}_{2}\right]$ & & 369.8 \\
\hline$\left[\right.$ ethoxycC $\left.{ }_{5} \mathrm{IM}\right]\left[\mathrm{NTf}_{2}\right]$ & & 355.4 \\
\hline$\left[\right.$ ethoxy3 $\left.\mathrm{C}_{5} \mathrm{IM}\right]\left[\mathrm{NTf}_{2}\right]$ & & 354.3 \\
\hline$\left[\mathrm{C}_{4} \mathrm{C}_{5} \mathrm{IM}\right]\left[\mathrm{NTf}_{2}\right]$ & & 413.2 \\
\hline$\left[\mathrm{C}_{4} \mathrm{iC}_{5} \mathrm{IM}\right]\left[\mathrm{NTf}_{2}\right]$ & & 402.3 \\
\hline$\left[\mathrm{C}_{4} \mathrm{cC}_{5} \mathrm{IM}\right]\left[\mathrm{NTf}_{2}\right]$ & & 365.9 \\
\hline$\left[\mathrm{C}_{4} 3 \mathrm{C}_{5} \mathrm{IM}\right]\left[\mathrm{NTf}_{2}\right]$ & & 362.9 \\
\hline
\end{tabular}

\subsection{Influence of Anions and Cations}

Anions play a major role in determining thermal stability, which has been confirmed in many studies $[46,58,59]$. For 1,2,4-triazolium ILs, the stability increases in the order $\left[\mathrm{NTf}_{2}\right]^{-}>[\mathrm{OTf}]^{-}>[\mathrm{OTs}]^{-}>\left[\mathrm{BF}_{4}\right]^{-}>[\mathrm{OMs}]^{-}>[\mathrm{I}]^{-}>\left[\mathrm{NO}_{3}\right]^{-}$(Table 10). For tributyltetradecyl phosphonium ILs, the stability increases in the order $[\mathrm{PFOS}]^{-}>\left[\mathrm{NPf}_{2}\right]^{-}>$ $\left[\mathrm{NTf}_{2}\right]^{-}>\left[\mathrm{FeCl}_{4}\right]^{-}>[\mathrm{AOT}]^{-}>[\mathrm{OS}]^{-}$(Table 11). For nitrile-functionalized azepanium ILs, the stability increases in the order $[\mathrm{OTf}]^{-}>[\mathrm{PTS}]^{-}>\left[\mathrm{CH}_{3} \mathrm{SO}_{4}\right]^{-}>[\mathrm{OMs}]^{-}>[\mathrm{Br}]^{-}$ $>[\text { TFA }]^{-}$(Table 12) For choline based amino acid ILs, the stability increases in the order

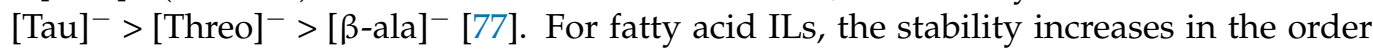
oleate $>$ linoleate $>$ caprylate $>$ caproate [121]. The influence of anions on the thermal 
stability for other cations has been compared in detail by Xue et al. [122]. In general, ILs with $\left[\mathrm{NTf}_{2}\right]^{-},\left[\mathrm{BF}_{4}\right]^{-}$or $\left[\mathrm{PF}_{6}\right]^{-}$perform better in heat resistance, and imidazolium, pyrrolidinium, and pyridinium are considered as cations with excellent thermal stability $[34,63,122]$.

Table 10. $\mathrm{T}_{\text {onset }}$ of 1,2,4-triazolium ILs at a heating rate of $10^{\circ} \mathrm{C} / \mathrm{min}$ in nitrogen atmosphere [78].

\begin{tabular}{|c|c|c|}
\hline ILs & Structure of Anions & $\mathrm{T}_{\text {onset }} /{ }^{\circ} \mathrm{C}$ \\
\hline $\begin{array}{c}\text { 4-methyl-1-propyl-1,2,4- } \\
\text { triazolium } \\
{\left[\mathrm{NTf}_{2}\right]}\end{array}$ & & 365 \\
\hline $\begin{array}{l}\text { 4-methyl-1-propyl-1,2,4- } \\
\text { triazolium } \\
\text { [OTf] }\end{array}$ & & 330 \\
\hline $\begin{array}{l}\text { 4-methyl-1-propyl-1,2,4- } \\
\text { triazolium } \\
{\left[\mathrm{BF}_{4}\right]}\end{array}$ & & 302 \\
\hline $\begin{array}{l}\text { 4-methyl-1-propyl-1,2,4- } \\
\text { triazolium } \\
\text { [PTs] }\end{array}$ & & 291 \\
\hline $\begin{array}{l}\text { 4-methyl-1-propyl-1,2,4- } \\
\text { triazolium } \\
\text { [OMs] }\end{array}$ & -0 & 267 \\
\hline $\begin{array}{l}\text { 4-methyl-1-propyl-1,2,4- } \\
\text { triazolium[I] }\end{array}$ & I- & 207 \\
\hline $\begin{array}{l}\text { 4-methyl-1-propyl-1,2,4- } \\
\text { triazolium } \\
{\left[\mathrm{NO}_{3}\right]}\end{array}$ & & 198 \\
\hline
\end{tabular}

Table 11. $\mathrm{T}_{5 \%}$ of tributyltetradecyl phosphonium ILs at a heating rate of $10{ }^{\circ} \mathrm{C} / \mathrm{min}$ in nitrogen atmosphere [37].

ILs


Table 11. Cont.

ILs Structure of Anions

Table 12. The thermal decomposition temperature of nitrile-functionalized azepanium ILs at a heating rate of $10^{\circ} \mathrm{C} / \mathrm{min}$ in an inert atmosphere [123].

ILs

\section{Thermal Stability of Some Novel ILs}

\subsection{ILs Mixtures}

Preparing IL mixtures is a simpler and more promising approach compared with developing new ILs. Figure 15 shows TGA curves of binary mixtures with different proportions of $\left[\mathrm{C}_{4} \mathrm{IM}\right]\left[\mathrm{BF}_{4}\right],\left[\mathrm{C}_{4} \mathrm{IM}\right]\left[\mathrm{NO}_{3}\right],\left[\mathrm{C}_{4} \mathrm{MIM}\right]\left[\mathrm{BF}_{4}\right]$ and $\left[\mathrm{C}_{4} \mathrm{MIM}\right]\left[\mathrm{NO}_{3}\right]$ [124]. It can 
be concluded that the thermal stability of binary mixtures is determined by the ILs which could be reconstituted by all ions in the mixture [125]. In other words, the anions and cations can combine freely in the mixture [111,112].
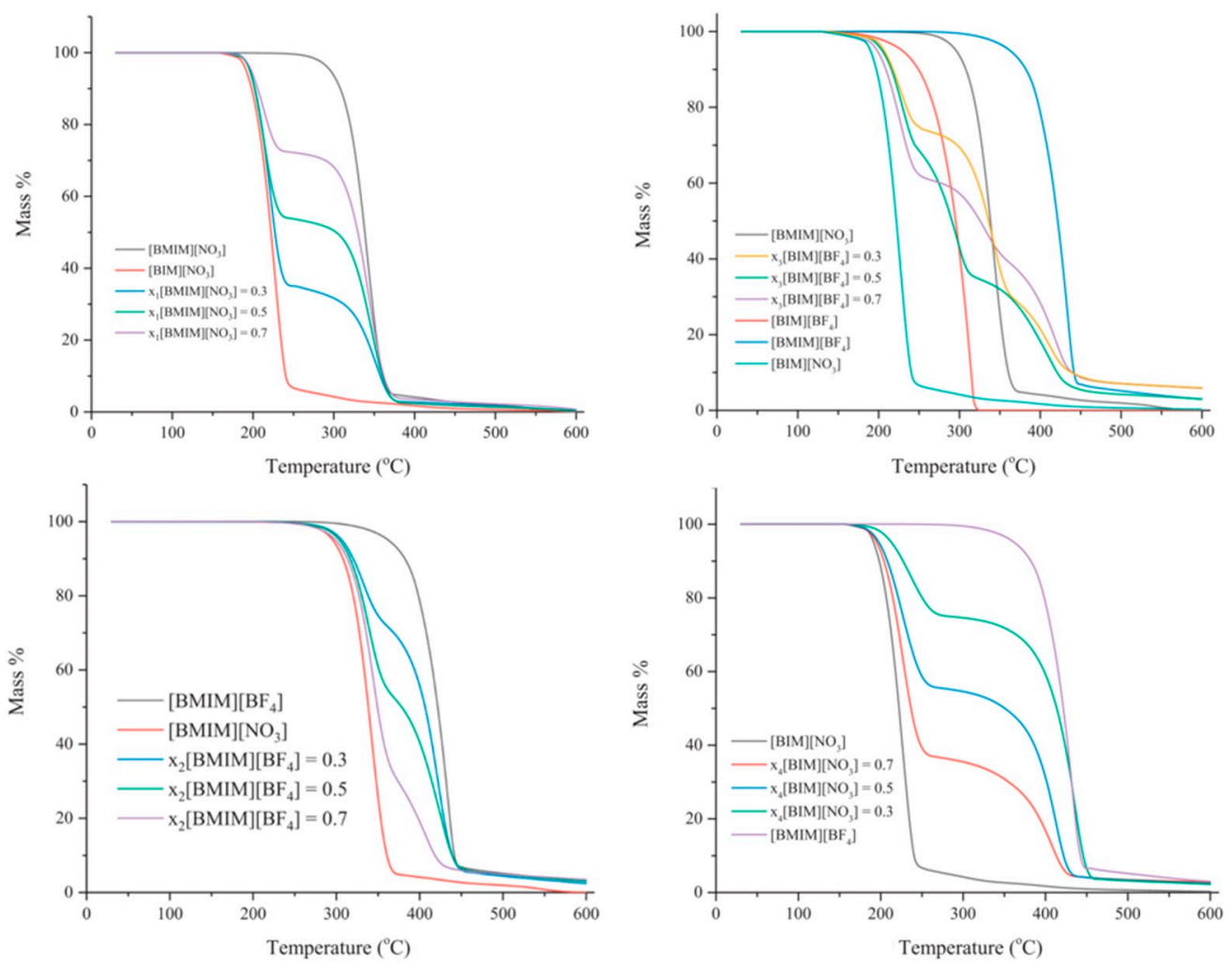

Figure 15. TGA curves of binary mixtures with different ILs and proportions at a heating rate of $10^{\circ} \mathrm{C} / \mathrm{min}$ in nitrogen atmosphere [124].

In order to predict the thermal stability of mixtures, Navarro et al. [126] proposed a method to obtain the mass loss of IL mixtures at different temperatures by using pure ILs TGA data as

$$
m_{\text {mixture }}=\sum_{l=1}^{L} w_{l} \cdot m_{l}
$$

where $m_{\text {mixture }}$ is the mass that the mixture would lose in an ideal case at each temperature, $m_{l}$ denotes the experimental mass loss of species in forming the mixture at a certain temperature, $w_{l}$ refers to the mass fraction of the $l$ th component in the mixture, and $L$ is the number of compounds involved in the mixture. This method has successfully predicted the thermal stability of several IL binary mixtures $[80,126,127]$. However, for the mixture of $\left[4 \mathrm{C}_{4} \mathrm{MPyr}\right]\left[\mathrm{NTf}_{2}\right]$ and $\left[\mathrm{C}_{2} \mathrm{MIM}\right]\left[\mathrm{EtSO}_{4}\right]$, the model cannot predict its thermal stability well, and this may be related to the strong interaction between $\left[\mathrm{EtSO}_{4}\right]^{-}$anion and the other ions in the mixture [128].

In addition, the study has revealed that mixing certain ILs in an appropriate ratio can improve thermal stability. TGA data of mixtures of $\left[\mathrm{C}_{4} \mathrm{MIM}\right]\left[\mathrm{NTf}_{2}\right]$ and $\left[\mathrm{C}_{8} \mathrm{MIM}\right][\mathrm{AcO}]$ in different proportions proves that when the mole fraction of $\left[\mathrm{C}_{8} \mathrm{MIM}\right][\mathrm{AcO}]$ is between 0.1 and $0.3, \mathrm{~T}_{5 \%}$ and $\mathrm{T}_{10 \%}$ are significantly higher than the values predicted by Equation (30) [64]. The results of nuclear magnetic resonance (NMR) indicate that the synergistic role of hydrogen bond and electrostatic interactions are proposed as the main reason for the improvement of the thermal stability of the IL mixtures. 


\subsection{Dicationic ILs}

Due to their unique properties, dicationic ILs (DILs) have been widely used in thermal storage [67,129], organic synthesis [130], anti-corrosion [131], or as surface-active agents [132], and they are less toxic than their monocationic counterparts [133].

The $\mathrm{T}_{\text {onset }}$ of monocationic ILs [ $\left.\mathrm{C}_{10} \mathrm{MIM}\right][\mathrm{Br}],\left[\mathrm{C}_{12} \mathrm{MIM}\right][\mathrm{Br}]$ and $\left[\mathrm{C}_{14} \mathrm{MIM}\right][\mathrm{Br}]$, and dicationic ILs $\left[\mathrm{C}_{10}(\mathrm{MIM})_{2}\right][\mathrm{Br}]_{2,}\left[\mathrm{C}_{12}(\mathrm{MIM})_{2}\right][\mathrm{Br}]_{2}$ and $\left[\mathrm{C}_{14}(\mathrm{MIM})_{2}\right][\mathrm{Br}]_{2}$, are shown in Figure 16. The values of DILs are $30-40{ }^{\circ} \mathrm{C}$ higher than their monocationic counterparts [134-136]. Other studies have obtained similar conclusions, which are ascribed to higher charges, higher molecular weight, and greater intermolecular interactions of DILs $[6,129,137]$. Due to their stronger electrostatic interactions, DILs often demonstrate higher melting points than monocationic ILs, which limits their applications [69]. Therefore, numerous methods of lowering melting points have been proposed, such as adjusting alkane linkage chain length, changing cationic head groups and anions, mixing DILs with the same cationic head groups and anion but different alkane linkage chains [37], utilizing branched alkane linkage chains [69] and designing unsymmetrical DILs [138].

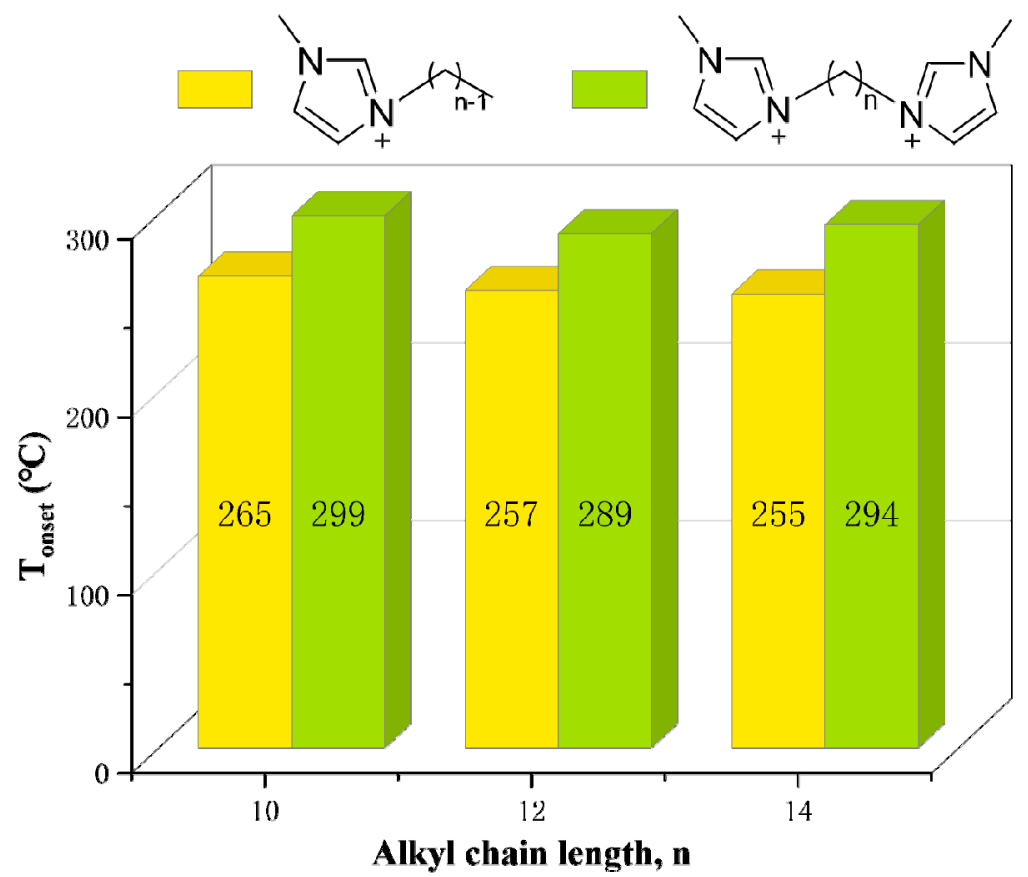

Figure 16. $T_{\text {onset }}$ of $\left[\mathrm{C}_{\mathrm{n}} \mathrm{MIM}\right][\mathrm{Br}]$ and $\left[\mathrm{C}_{\mathrm{n}}(\mathrm{MIM})_{2}\right][\mathrm{Br}]_{2}$ obtained by TGA at a heating rate of $10^{\circ} \mathrm{C} / \mathrm{min}$ in nitrogen atmosphere $[134](n=10,12,14)$.

As shown in Table 13, when the linkage chain is the same, the thermal stability of DILs with cationic head groups of (MMIM), $\left(\mathrm{C}_{1} \mathrm{Py}\right)$, and $\left(\mathrm{PC}_{3} \mathrm{C}_{3} \mathrm{C}_{3}\right)$ is significantly different. Moreover, Figure 17 suggests that the longer the alkyl side chains are, the lower the thermal stability of DILs are. The reduced thermal stability is attributed to the decreasing symmetry of cations with the increase of the number of carbon atoms in the alkyl side chains, which hinders the crystal effective accumulation [129,139]. Table 14 demonstrates that the decomposition temperatures of DILs with some functional groups are higher than those of DILs without corresponding functional groups. This might be explained by the appearance of complex functional groups increasing the strength of intermolecular interaction and the energy of chemical bonds [139]. 
Table 13. Thermal stability of dicationic ILs (DILs) containing different cationic head groups at a heating rate of $10^{\circ} \mathrm{C} / \mathrm{min}$ in nitrogen atmosphere [69].

\begin{tabular}{ccccc}
\hline DILs & $\mathrm{T}_{0.05} /{ }^{\circ} \mathbf{C}$ & $\mathrm{T}_{\mathbf{0 . 1 5}} /{ }^{\circ} \mathbf{C}$ \\
{$\left[\mathrm{C}_{3} 2 \mathrm{M}(\mathrm{MMIM})_{2}\right]\left[\mathrm{NTf}_{2}\right]_{2}$} & & 438 \\
{$\left[\mathrm{C}_{3} 2 \mathrm{M}\left(\mathrm{C}_{1} \mathrm{Py}_{2}\right]\left[\mathrm{NTf}_{2}\right]_{2}\right.$}
\end{tabular}

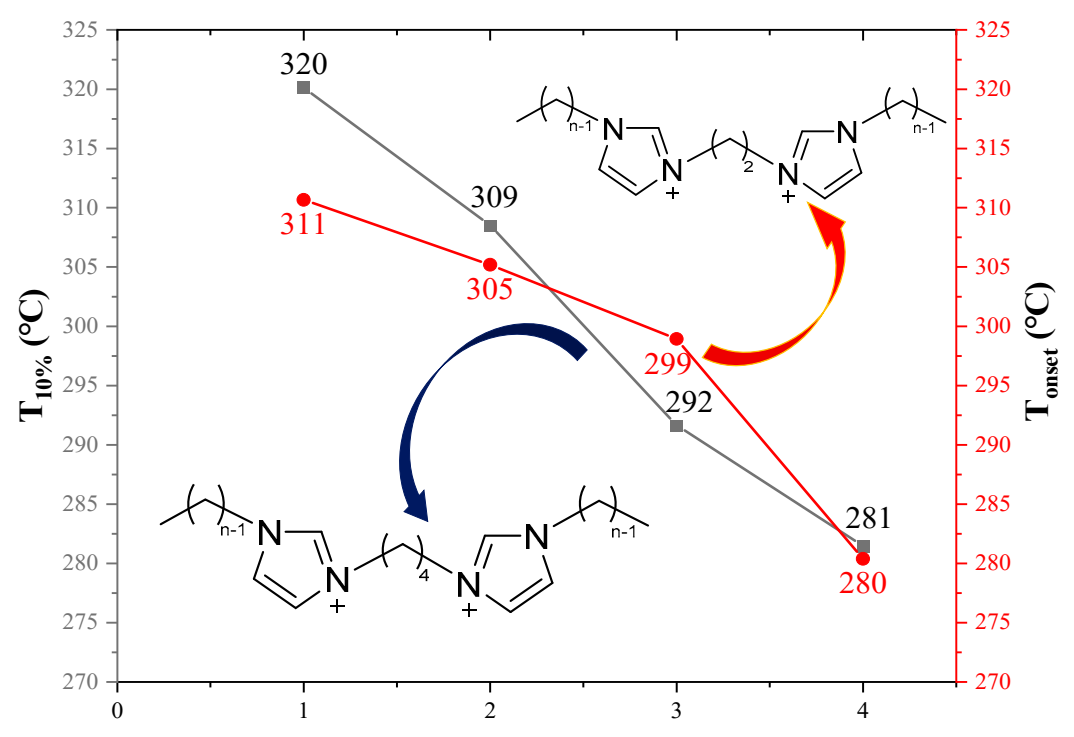

Alkyl chain length, $n$

Figure 17. Thermal decomposition temperature of $\left[\mathrm{C}_{2}\left(\mathrm{C}_{n} \mathrm{IM}\right)_{2}\right][\mathrm{Br}]_{2}$ and $\left[\mathrm{C}_{4}\left(\mathrm{C}_{n} \mathrm{IM}\right)_{2}\right][\mathrm{Br}]_{2}$ at a heating rate of $10{ }^{\circ} \mathrm{C} / \mathrm{min}$ in nitrogen atmosphere $[129,139](n=1-4)$.

Table 14. $\mathrm{T}_{\text {onset }}$ of DILs with different functional groups at a heating rate of $10{ }^{\circ} \mathrm{C} / \mathrm{min}$ in nitrogen atmosphere [139].

$\left[\mathrm{C}_{4}\left(\mathrm{C}_{2} \mathrm{IM}\right)_{2}\right][\mathrm{Br}]_{2}$


The change of the linkage chain between the two cationic head groups also has an important influence on thermal stability. The linkage chain is usually a straight-chain alkyl, and a longer linkage chain leads to worse thermal stability within a certain range, while a further increase in chain length leads to the decrease of thermal stability [37]. DILs with the branched linkage chain are developed due to reducing the high melting point of DILs with a straight linkage chain. Although the thermal stability of DILs containing the branched alkyl linkage chain is lower than their linear counterparts, it should be noted that this discrepancy is acceptable when the length of the linkage chain reaches $C_{5}$. Therefore, the thermal stability of DILs can be tuned by branching linkage chains [69]. Recently, DILs with m-xylyl, pyridine functional groups, and dioxane linkage chain have been synthesized, and all of them have a low melting point and high thermal stability [140-142]. Similar to monocationic ILs, anions have a major influence in the thermal stability of DILs, and Table 15 reveals that the thermal stability order is as follows: $\left[\mathrm{NTf}_{2}\right]^{-}>\left[\mathrm{PF}_{6}\right]^{-}>\left[\mathrm{BF}_{4}\right]^{-}$ $>[\mathrm{OTf}]^{-}>[\mathrm{Cl}]^{-}[129,141]$. The $\left[\mathrm{NTf}_{2}\right]^{-}$DILs also have high thermal stability and low melting point $[37,138,140]$. Generally, the influence factors of DILs structure on thermal stability are similar to monocationic ILs. Therefore, the properties of DILs that have not been determined by experiments can be inferred from the known monocationic ILs.

Table 15. The decomposition temperature of DILs with different anions at a heating rate of $10^{\circ} \mathrm{C} / \mathrm{min}$ in nitrogen atmosphere $[129,141]$. Reproduced with permission from Jianlian Liu, Journal of Molecular Liquids; published by Elsevier, 2020; reproduced with permission from Coby J. Clarke, ACS Sustainable Chemistry E Engineering; published by American Chemical Society, 2020.

\begin{tabular}{|c|c|}
\hline DILs & Decomposition Temperature $/{ }^{\circ} \mathrm{C}$ \\
\hline$\left[\operatorname{Pyri}\left(\mathrm{C}_{8} \mathrm{MIM}\right)_{2}\right][\mathrm{Cl}]_{2}$ & $273.2^{\mathrm{a}}$ \\
\hline$\left[\operatorname{Pyri}\left(\mathrm{C}_{8} \mathrm{MIM}\right)_{2}\right][\mathrm{OTf}]_{2}$ & $417.8^{\text {a }}$ \\
\hline$\left[\right.$ Pyri $\left.\left(\mathrm{C}_{8} \mathrm{MIM}\right)_{2}\right]\left[\mathrm{BF}_{4}\right]_{2}$ & $419.1^{\mathrm{a}}$ \\
\hline$\left[\operatorname{Pyri}\left(\mathrm{C}_{8} \mathrm{MIM}\right)_{2}\right]\left[\mathrm{PF}_{6}\right]_{2}$ & $429.4^{\mathrm{a}}$ \\
\hline$\left[\operatorname{Pyri}\left(\mathrm{C}_{8} \mathrm{MIM}\right)_{2}\right]\left[\mathrm{NTf}_{2}\right]_{2}$ & $443.5^{\mathrm{a}}$ \\
\hline$\left[\mathrm{C}_{4}(\mathrm{MIM})_{2}\right]\left[\mathrm{BF}_{4}\right]_{2}$ & $384.6^{b}$ \\
\hline$\left[\mathrm{C}_{4}(\mathrm{MIM})_{2}\right]\left[\mathrm{PF}_{6}\right]_{2}$ & $423.4^{b}$ \\
\hline$\left[\mathrm{C}_{4}(\mathrm{MIM})_{2}\right]\left[\mathrm{NTf}_{2}\right]_{2}$ & $468.1^{\mathrm{b}}$ \\
\hline
\end{tabular}

${ }^{\mathrm{a}} \mathrm{T}_{\text {onset }}$ from [141]; ${ }^{\mathrm{b}} \mathrm{T}_{10 \%}$ from [129].

\section{Summary}

The methods measuring the thermal stability of ILs are discussed. Although $\mathrm{T}_{\text {onset }}$ overestimates the thermal stability, it is still used as a universal parameter in different investigations. It should be noted that when using $\mathrm{T}_{\text {onset }}$ to compare the thermal stability it is necessary to determine whether the experimental conditions (atmosphere type, heating rate, etc.) are the same. Although $\mathrm{T}_{\mathrm{z} / \mathrm{y}}$ is defined as a parameter to measure the longterm thermal stability of ILs, it is clear that this parameter cannot meet the required time of industrial running. Thus, a series of methods have been proposed to predict the thermal stability of ILs over a longer period. Among them, MOT is considered a highly accurate method, and the activation energy and pre-exponential factor values in the thermal decomposition process are required for calculating MOT.

Different means to study the thermal degradation kinetics of ILs are elaborated. After extensively analyzing the kinetic data from several investigations, it can be concluded that the isoconversional methods have been widely used to calculate the activation energy values, and the results of integral isoconversional methods are more accurate than those of differential methods. In addition, maximum-rate methods and Arrhenius methods are used in many research studies due to their simple calculation process, although both methods are not as precise as isoconversional methods. The Arrhenius method is also used to calculate the pre-exponential factor. However, compensation effect or master plots are seen lately as reliable tools for calculating pre-exponential factor values. 
Thermal stability data of divergent ILs are summarized in Table 16 according to the types of anions, and this table reveals many structural factors affecting thermal stability, in which the modification of cations is the prime research object. For cations, a longer alkyl side chain, functionalization, and the bonding of alkyl chain via tertiary carbon atom all reduce the thermal stability of ILs. In the process of etherification, the number and position of oxygen atoms and the length of the O-alkyl chain have evident effects on thermal stability. Moreover, due to the high acidity of the $\mathrm{C} 2$ proton, methyl substitution in the $\mathrm{C} 2$ position on the imidazolium ring can improve the thermal stability. Although there are many methods to change the thermal stability by tuning cations, it should be stressed that the type of anions plays a major role in determining thermal stability. Generally, some specific anions such as $\left[\mathrm{NTf}_{2}\right]^{-},\left[\mathrm{BF}_{4}\right]^{-}$, and $\left[\mathrm{PF}_{6}\right]^{-}$and cations such as imidazolium, pyrrolidinium, and pyridinium make the ILs more stable at high temperatures.

Table 16. Decomposition temperature and activation energy of some ILs and DILs.

\begin{tabular}{|c|c|c|c|c|c|c|c|}
\hline No. & ILs & $\mathrm{T}_{\text {onset }} /{ }^{\circ} \mathrm{C}$ & $\mathrm{T}_{5 \%} /{ }^{\circ} \mathrm{C}$ & $\mathrm{T}_{10 \%} /{ }^{\circ} \mathrm{C}$ & $\mathrm{T}_{\text {peak }} /{ }^{\circ} \mathrm{C}$ & $\mathrm{E} / \mathrm{kJ} \mathrm{mol} \mathbf{~}^{-1}$ & Ref. \\
\hline \multicolumn{8}{|c|}{ Monocationic ILs } \\
\hline & & 263 & & & & $122^{a}$ & [57] \\
\hline 1 & {$\left[\mathrm{C}_{2} \mathrm{MIM}\right][\mathrm{Cl}]$} & 260 & & & & $120^{\mathrm{b}}$ & [39] \\
\hline 2 & {$\left[\mathrm{C}_{3} \mathrm{MIM}\right][\mathrm{Cl}]$} & 246 & & & & $155^{\mathrm{a}}$ & [57] \\
\hline \multirow{2}{*}{3} & \multirow{2}{*}[\mathrm{C}_{4}\mathrm{MIM}]{$[\mathrm{Cl}]$} & 260 & & & & $151^{\mathrm{a}}$ & [57] \\
\hline & & 250 & & & & $105^{b}$ & [39] \\
\hline 4 & {$\left[\mathrm{C}_{4} \mathrm{MMIM}\right][\mathrm{Cl}]$} & 267 & & & & $58.688^{\mathrm{b}}$ & [86] \\
\hline 5 & {$\left[\mathrm{C}_{6} \mathrm{MIM}\right][\mathrm{Cl}]$} & 253 & & & & $98^{\mathrm{a}}$ & [57] \\
\hline 6 & {$\left[\mathrm{C}_{10} \mathrm{MIM}\right][\mathrm{Cl}]$} & 247 & & & & $150^{\mathrm{a}}$ & [57] \\
\hline 7 & {$\left[\mathrm{C}_{3} \mathrm{OHMIM}\right][\mathrm{Cl}]$} & 295 & & & & & [113] \\
\hline 8 & {$\left[\mathrm{P}_{6,6,6,14}\right][\mathrm{Cl}]$} & 320 & & & & & [40] \\
\hline 9 & {$\left[\mathrm{C}_{2} \mathrm{MIM}\right][\mathrm{Br}]$} & 283 & & & & $125^{b}$ & [39] \\
\hline 10 & {$\left[\mathrm{C}_{4} \mathrm{MIM}\right][\mathrm{Br}]$} & 255 & & & & $127^{b}$ & [39] \\
\hline 11 & {$\left[\mathrm{C}_{10} \mathrm{MIM}\right][\mathrm{Br}]$} & 265 & & & 298 & & [134] \\
\hline 12 & {$\left[\mathrm{C}_{12} \mathrm{MIM}\right][\mathrm{Br}]$} & 257 & & & 292 & & [134] \\
\hline 13 & {$\left[\mathrm{C}_{14} \mathrm{MIM}\right][\mathrm{Br}]$} & 255 & & & 287 & & [134] \\
\hline 14 & {$\left[\mathrm{C}_{2} \mathrm{NH}_{2} \mathrm{MIM}\right][\mathrm{Br}]$} & 222 & & & & & [113] \\
\hline 15 & {$\left[\mathrm{C}_{4 \mathrm{CN}} \mathrm{Azp}\right][\mathrm{Br}]$} & & 216 & & & & [123] \\
\hline 16 & {$\left[\mathrm{C}_{2} \mathrm{MIM}\right][\mathrm{I}]$} & 279 & & & & $111^{b}$ & [39] \\
\hline 17 & {$\left[\mathrm{C}_{4} \mathrm{MIM}\right][\mathrm{I}]$} & 265 & & & & $121^{b}$ & [39] \\
\hline 18 & {$\left[\mathrm{C}_{3} \mathrm{MT}_{1,2,4} \mathrm{M}\right][\mathrm{I}]$} & 207 & 188 & & & $122.1^{\mathrm{c}}$ & [78] \\
\hline 19 & {$\left[\mathrm{C}_{2} \mathrm{MIM}\right]\left[\mathrm{NTf}_{2}\right]$} & 425 & 384 & 402 & 470 & $102^{\mathrm{b}} ; 108^{\mathrm{d}}$ & [44] \\
\hline \multirow{3}{*}{20} & \multirow{3}{*}[\mathrm{C}_{3}\mathrm{MIM}]{$\left[\mathrm{NTf}_{2}\right]$} & 406 & 358 & 379 & 448 & $92^{b} ; 98^{d}$ & [44] \\
\hline & & 412 & 369 & & & $115.8^{\mathrm{c}}$ & [78] \\
\hline & & 426 & 385 & 405 & 466 & $125^{\mathrm{b}} ; 130^{\mathrm{d}}$ & [44] \\
\hline \multirow{3}{*}{21} & \multirow{3}{*}[\mathrm{C}_{4}\mathrm{MIM}]{$\left[\mathrm{NTf}_{2}\right]$} & 421 & & & 478 & & [58] \\
\hline & & 367 & & & 465 & $115.9^{\mathrm{b}} ; 121.3^{\mathrm{d}} ; 116.3^{\mathrm{a}}$ & {$[18]$} \\
\hline & & 418 & 385 & & & $130.7^{c}$ & [75] \\
\hline \multirow[b]{2}{*}{22} & \multirow{2}{*}[\mathrm{C}_{4}\mathrm{MMIM}]{$\left[\mathrm{NTf}_{2}\right]$} & 418 & 374 & 394 & 468 & $119^{b} ; 124^{d}$ & [44] \\
\hline & & 436 & & 408 & 478 & $129^{\mathrm{c}}$ & {$[47]$} \\
\hline 23 & {$\left[\mathrm{C}_{7} \mathrm{MIM}\right]\left[\mathrm{NTf}_{2}\right]$} & 437 & & 426 & 464 & & [110] \\
\hline 24 & {$\left[\mathrm{C}_{12} \mathrm{MIM}\right]\left[\mathrm{NTf}_{2}\right]$} & 405 & & 418 & 464 & $125^{b}$ & [49] \\
\hline 25 & {$\left[\mathrm{~N}_{4,4,4,1}\right]\left[\mathrm{NTf}_{2}\right]$} & 380 & & 374 & 435 & $121^{b}$ & [49] \\
\hline 26 & {$\left[\mathrm{~N}_{8,8,8,1}\right]\left[\mathrm{NTf}_{2}\right]$} & 362 & & 386 & 425 & $108^{b}$ & [49] \\
\hline 27 & {$\left[\mathrm{P}_{4,4,4,14}\right]\left[\mathrm{NTf}_{2}\right]$} & & 405 & & & & [37] \\
\hline 28 & {$\left[\mathrm{C}_{3} \mathrm{MPy}\right]\left[\mathrm{NTf}_{2}\right]$} & 469 & & & & & [72] \\
\hline 29 & {$\left[\mathrm{C}_{4} \mathrm{MPy}\right]\left[\mathrm{NTf}_{2}\right]$} & 451 [66] & & & 450 & $128.6^{\mathrm{d}} ; 123.6^{\mathrm{b}} ; 124.0^{\mathrm{a}}[50]$ & \\
\hline 30 & {$\left[\mathrm{C}_{5} \mathrm{MPy}\right]\left[\mathrm{NTf}_{2}\right]$} & 443 & & & & & [72] \\
\hline
\end{tabular}


Table 16. Cont.

\begin{tabular}{|c|c|c|c|c|c|c|c|}
\hline No. & ILs & $\mathrm{T}_{\text {onset }} /{ }^{\circ} \mathrm{C}$ & $\mathrm{T}_{5 \%} /{ }^{\circ} \mathrm{C}$ & $\mathrm{T}_{10 \%} /{ }^{\circ} \mathrm{C}$ & $\mathrm{T}_{\text {peak }} /{ }^{\circ} \mathrm{C}$ & $\mathrm{E} / \mathrm{kJ} \mathrm{mol}^{-1}$ & Ref. \\
\hline 31 & {$\left[\mathrm{C}_{6} \mathrm{MPy}\right]\left[\mathrm{NTf}_{2}\right]$} & 440 & & & & & [72] \\
\hline 32 & {$\left[\mathrm{C}_{7} \mathrm{MPy}\right]\left[\mathrm{NTf}_{2}\right]$} & 429 & & & & & [72] \\
\hline 33 & {$\left[\mathrm{C}_{8} \mathrm{MPy}\right]\left[\mathrm{NTf}_{2}\right]$} & $443[66]$ & & & $447[50]$ & $113.7^{\mathrm{d}} ; 107.8^{\mathrm{b}} ; 108.2^{\mathrm{a}}[50]$ & \\
\hline 34 & {$\left[\mathrm{C}_{9} \mathrm{MPy}\right]\left[\mathrm{NTf}_{2}\right]$} & 447 & & & & & {$[72]$} \\
\hline 35 & {$\left[\mathrm{C}_{10} \mathrm{MPy}\right]\left[\mathrm{NTf}_{2}\right]$} & 421 & & & & & [72] \\
\hline 36 & {$\left[\mathrm{C}_{1} \mathrm{OC}_{2} \mathrm{MPy}\right]\left[\mathrm{NTf}_{2}\right]$} & 411 & & 399 & 443 & & [63] \\
\hline 37 & {$\left[\mathrm{C}_{2} \mathrm{MT}_{1,2,4} \mathrm{M}\right]\left[\mathrm{NTf}_{2}\right]^{\mathrm{e}}$} & 355 & 327 & & & $102.5^{\mathrm{c}}$ & [75] \\
\hline 38 & {$\left[\mathrm{C}_{3} \mathrm{MT}_{1,2,4} \mathrm{M}\right]\left[\mathrm{NTf}_{2}\right]^{\mathrm{e}}$} & 365 & 337 & & & $110.3^{\mathrm{c}}$ & [75] \\
\hline 39 & {$\left[\mathrm{C}_{4} \mathrm{MT}_{1,2,4} \mathrm{M}\right]\left[\mathrm{NTf}_{2}\right]^{\mathrm{e}}$} & 350 & 327 & & & $114.8^{\mathrm{c}}$ & [75] \\
\hline 40 & {$\left[\mathrm{C}_{6} \mathrm{MT}_{1,2,4} \mathrm{M}\right]\left[\mathrm{NTf}_{2}\right]^{\mathrm{e}}$} & 345 & 318 & & & $119.1^{\mathrm{c}}$ & [75] \\
\hline 41 & {$\left[\mathrm{C}_{8} \mathrm{MT}_{1,2,4} \mathrm{M}\right]\left[\mathrm{NTf}_{2}\right]^{\mathrm{e}}$} & 346 & 318 & & & $123.6^{\mathrm{c}}$ & [75] \\
\hline 42 & {$\left[\mathrm{C}_{10} \mathrm{MT}_{1,2,4} \mathrm{M}\right]\left[\mathrm{NTf}_{2}\right]^{\mathrm{e}}$} & 357 & 331 & & & $127.7^{\mathrm{c}}$ & [75] \\
\hline 43 & {$\left[\mathrm{C}_{12} \mathrm{MT}_{1,2,4} \mathrm{M}\right]\left[\mathrm{NTf}_{2}\right]^{\mathrm{e}}$} & 354 & 326 & & & $131.6^{\mathrm{c}}$ & [75] \\
\hline 44 & {$\left[\right.$ BnzMIM] $\left[\mathrm{NTf}_{2}\right]$} & 421 & & 402 & 464 & & [110] \\
\hline 45 & {$\left[(\mathrm{Bnz})_{2} \mathrm{IM}\right]\left[\mathrm{NTf}_{2}\right]$} & 410 & & 391 & 453 & & [110] \\
\hline 46 & {$\left[\right.$ NapmMIM] $\left[\mathrm{NTf}_{2}\right]$} & 406 & & 392 & 460 & & [110] \\
\hline 47 & {$\left[\mathrm{PP}_{16}\right]\left[\mathrm{NTf}_{2}\right]$} & & & 385 & & & [117] \\
\hline 48 & {$\left[\mathrm{PP}_{1 \mathrm{EP}}\right]\left[\mathrm{NTf}_{2}\right]$} & & & 349 & & & [117] \\
\hline 49 & {$\left[\mathrm{PP}_{1 \mathrm{PE}}\right]\left[\mathrm{NTf}_{2}\right]$} & & & 348 & & & [117] \\
\hline 50 & {$\left[\mathrm{PP}_{1 \mathrm{MB}}\right]\left[\mathrm{NTf}_{2}\right]$} & & & 314 & & & [117] \\
\hline 51 & {$\left[\mathrm{PP}_{1 \mathrm{MEM}}\right]\left[\mathrm{NTf}_{2}\right]$} & & & 268 & & & [117] \\
\hline 52 & {$\left[\mathrm{PP}_{1 \mathrm{BM}}\right]\left[\mathrm{NTf}_{2}\right]$} & & & 259 & & & [117] \\
\hline 53 & {$\left[\mathrm{PP}_{1 \mathrm{MEEM}}\right]\left[\mathrm{NTf}_{2}\right]$} & & & 253 & & & [117] \\
\hline 54 & [ethoxy $\left.\mathrm{C}_{5} \mathrm{IM}\right]\left[\mathrm{NTf}_{2}\right]$ & & 377.3 & & & & [66] \\
\hline 55 & {$\left[\right.$ ethoxyiC $\left.{ }_{5} \mathrm{IM}\right]\left[\mathrm{NTf}_{2}\right]$} & & 372.7 & & & & [66] \\
\hline 56 & [ethoxyneoC $\left.{ }_{5} \mathrm{IM}\right]\left[\mathrm{NTf}_{2}\right]$ & & 369.8 & & & & [66] \\
\hline 57 & {$\left[\right.$ ethoxycC $\left.\mathrm{C}_{5} \mathrm{IM}\right]\left[\mathrm{NTf}_{2}\right]$} & & 355.4 & & & & [66] \\
\hline 58 & [ethoxy $\left.3 \mathrm{C}_{5} \mathrm{IM}\right]\left[\mathrm{NTf}_{2}\right]$ & & 354.3 & & & & [66] \\
\hline 59 & {$\left[\mathrm{C}_{4} \mathrm{C}_{5} \mathrm{IM}\right]\left[\mathrm{NTf}_{2}\right]$} & & 413.2 & & & & [66] \\
\hline 60 & {$\left[\mathrm{C}_{4} \mathrm{iC}_{5} \mathrm{IM}\right]\left[\mathrm{NTf}_{2}\right]$} & & 402.3 & & & & [66] \\
\hline 61 & {$\left[\mathrm{C}_{4} \mathrm{CC}_{5} \mathrm{IM}\right]\left[\mathrm{NTf}_{2}\right]$} & & 365.9 & & & & [66] \\
\hline 62 & {$\left[\mathrm{C}_{4} 3 \mathrm{C}_{5} \mathrm{IM}\right]\left[\mathrm{NTf}_{2}\right]$} & & 362.9 & & & & [66] \\
\hline 63 & {$\left[\mathrm{C}_{4} \mathrm{MIM}\right][\mathrm{PTs}]$} & 346 & & & 379 & & [58] \\
\hline 64 & {$\left[\mathrm{C}_{3} \mathrm{MT}_{1,2,4} \mathrm{M}\right][\mathrm{PTs}]^{\mathrm{e}}$} & 291 & 271 & & & $141.8^{\mathrm{c}}$ & [78] \\
\hline 65 & {$\left[\mathrm{C}_{4 \mathrm{CN}} \mathrm{Azp}\right][\mathrm{PTs}]$} & & 240 & & & & [123] \\
\hline 66 & [Chol][Tos] & 332 & & & 346 & & [73] \\
\hline 67 & {$\left[\mathrm{C}_{2} \mathrm{Py}\right][\mathrm{Tos}]$} & 335 & & & 357 & & [73] \\
\hline 68 & [Chol][Ac] & 200 & & & 222 & & [73] \\
\hline 69 & {$\left[\mathrm{C}_{2} \mathrm{MIM}\right][\mathrm{Ac}]$} & 221 & & & & & [85] \\
\hline 70 & {$\left[\mathrm{C}_{4} \mathrm{MIM}\right][\mathrm{OS}]$} & 314 & & & 353 & & [58] \\
\hline 71 & {$\left[\mathrm{P}_{4,4,4,14}\right][\mathrm{OS}]$} & & 194 & & & & [37] \\
\hline 72 & {$[\mathrm{MIM}]\left[\mathrm{NO}_{3}\right]$} & 163 & & & 184 & $112.7^{\mathrm{d}}$ & [90] \\
\hline 73 & {$\left[\mathrm{C}_{3} \mathrm{MT}_{1,2,4} \mathrm{M}\right]\left[\mathrm{NO}_{3}\right]^{\mathrm{e}}$} & 198 & 187 & & & $132.1^{\mathrm{c}}$ & [78] \\
\hline 74 & {$\left[\mathrm{C}_{3} \mathrm{MT}_{1,2,4} \mathrm{M}\right][\mathrm{OMs}]^{\mathrm{e}}$} & 267 & 254 & & & $138.9^{\mathrm{c}}$ & [78] \\
\hline 75 & {$\left[\mathrm{C}_{4 \mathrm{CN}} \mathrm{Azp}\right][\mathrm{OMs}]$} & & 220 & & & & [123] \\
\hline 76 & {$\left[\mathrm{C}_{4} \mathrm{MIM}\right][\mathrm{OTf}]$} & 382 & & & 420 & & [58] \\
\hline 77 & {$\left[\mathrm{C}_{4} \mathrm{MMIM}\right][\mathrm{OTf}]^{\mathrm{f}}$} & 436 & 424 & & 479 & $148^{\mathrm{c}}$ & [47] \\
\hline 78 & {$\left[\mathrm{C}_{3} \mathrm{MT}_{1,2,4} \mathrm{M}\right][\mathrm{OTf}]^{\mathrm{e}}$} & 365 & 337 & & & $110.3^{c}$ & [78] \\
\hline 79 & {$\left[\mathrm{C}_{4 \mathrm{CN}} \mathrm{Azp}\right][\mathrm{OTf}]$} & & 332 & & & & [123] \\
\hline 80 & {$\left[\mathrm{C}_{4} \mathrm{MIM}\right]\left[\mathrm{BF}_{4}\right]$} & 381 & & & 396 & & [58] \\
\hline 81 & {$\left[\mathrm{C}_{2} \mathrm{MMIM}\right]\left[\mathrm{BF}_{4}\right]$} & 391 & & & & & [101] \\
\hline 82 & {$\left[\mathrm{C}_{2} \mathrm{NH}_{2} \mathrm{MMIM}\right]\left[\mathrm{BF}_{4}\right]$} & 284 & & & & $72.2^{c}$ & [101] \\
\hline 83 & {$\left[\mathrm{C}_{3} \mathrm{MT}_{1,2,4} \mathrm{M}\right]\left[\mathrm{BF}_{4}\right]^{\mathrm{e}}$} & 302 & 264 & & & $102.2^{\mathrm{c}}$ & [78] \\
\hline 84 & {$\left[\mathrm{C}_{1} \mathrm{OC}_{2} \mathrm{MPy}\right]\left[\left(\mathrm{C}_{2} \mathrm{~F}_{5}\right)_{3} \mathrm{PF}_{3}\right]$} & 352 & & 349 & 384 & & [63] \\
\hline 85 & {$\left[\mathrm{P}_{6,6,6,14}\right]\left[\left(\mathrm{C}_{2} \mathrm{~F}_{5}\right)_{3} \mathrm{PF}_{3}\right]$} & 363 & & 356 & 396 & & [63] \\
\hline
\end{tabular}


Table 16. Cont.

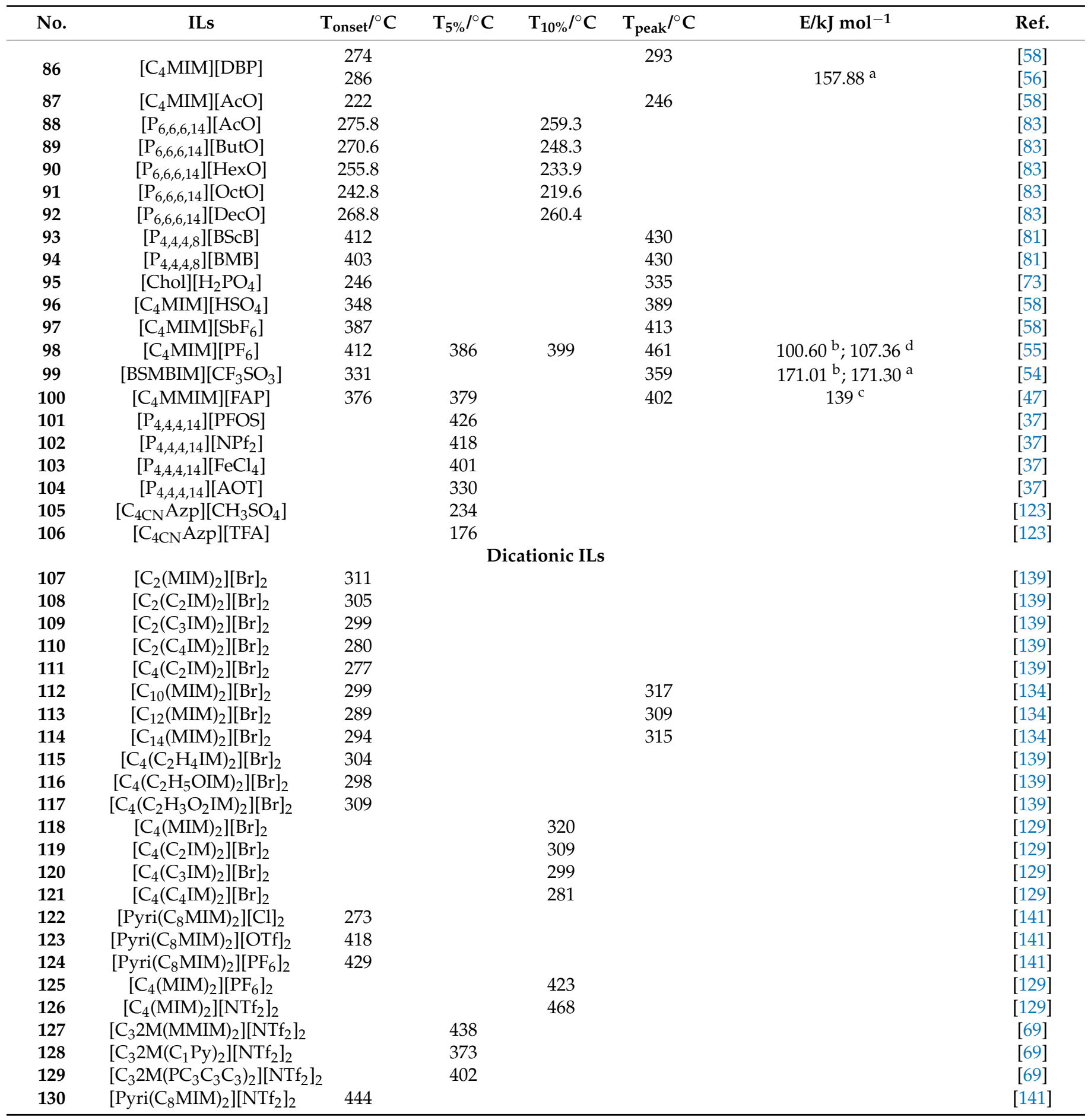

All TGA experiments were performed under an $\mathrm{N}_{2}$ atmosphere and at a heating rate of $10{ }^{\circ} \mathrm{C} / \mathrm{min}$ unless indicated. In ref. [44,63,85,90] an air atmosphere was used, and in ref. [66], an argon atmosphere was used. In ref. [56,90] the heating rate was $8{ }^{\circ} \mathrm{C} / \mathrm{min}$, and in ref. [83], the heating rate was $5{ }^{\circ} \mathrm{C} / \mathrm{min} .{ }^{a}$ Starink method; ${ }^{\mathrm{b}} \mathrm{KAS}$ method; ${ }^{\mathrm{c}}$ zero-order Arrhenius method; ${ }^{\mathrm{d}}$ Flynn-Wall-Ozawa (FWO) method; ${ }^{\mathrm{e}} \mathrm{T}_{1,2,4} \mathrm{M}$ denotes 1,2,4-triazolium; ${ }^{\mathrm{f}}$ in the air atmosphere; reproduced with permission from Asli Akçay, Thermochimica Acta; published by Elsevier, 2014; reproduced with permission from Wenlong Wang, Chemical Engineering Journal; published by Elsevier, 2017; reproduced with permission from Andreah T. De La Hoz, The Journal of Physical Chemistry B; published by American Chemical Society, 2014; reproduced with permission from Josefa Salgado, The Journal of Chemical Thermodynamics; published by Elsevier, 2013; reproduced with permission from Samuel M. Murray, Journal of Chemical E Engineering Data; published by American Chemical Society, 2013; reproduced with permission from D. Blanco, Thermochimica Acta; published by Elsevier, 2017; reproduced with permission from Rahul A. Patil, Chemistry of Materials; published by American Chemical Society, 2016; reproduced with permission from Gebrekidan Gebresilassie Eshetu, ChemSusChem; published by Wiley, 2017; reproduced with permission from Khurrum Shehzad Quraishi, Journal of Thermal Analysis and Calorimetry; published by Springer Nature, 2017; reproduced with permission from Juan J. Parajó, The Journal of Chemical Thermodynamics; 
published by Elsevier, 2018; reproduced with permission from T. Nokami, Faraday Discussions; published by Royal Society of Chemistry, 2018; reproduced with permission from Jan Rotrekl, Fluid Phase Equilibria; published by Elsevier, 2020; reproduced with permission from J.J.Parajó, The Journal of Chemical Thermodynamics; published by Elsevier, 2020; reproduced with permission from Nana Yamaki, Journal of Thermal Analysis and Calorimetry; published by Springer Nature, 2019; reproduced with permission from Vikranth Volli, Journal of Thermal Analysis and Calorimetry; published by Springer Nature, 2019; reproduced with permission from Shuangyue Liu, Journal of Molecular Liquids; published by Elsevier, 2015; reproduced with permission from Hui-Chun Jiang, Journal of Thermal Analysis and Calorimetry; published by Springer Nature, 2019; reproduced with permission from K. Oster, The Journal of Chemical Thermodynamics; published by Elsevier, 2018; reproduced with permission from Faiz Ullah Shah, Molecules; published by Molecular Diversity Preservation International, 2020; reproduced with permission from Zhen Huang, Journal of Thermal Analysis and Calorimetry; published by Springer Nature, 2019; reproduced with permission from Zahoor Ullah, Procedia Engineering; published by Elsevier, 2016; reproduced with permission from Hang Zhang, The Journal of Physical Chemistry C; published by American Chemical Society, 2018; reproduced with permission from Jianlian Liu, Journal of Molecular Liquids; published by Elsevier, 2020; reproduced with permission from Coby J. Clarke, ACS Sustainable Chemistry $\mathcal{E}$ Engineering; published by American Chemical Society, 2020; reproduced with permission from Mohsen Talebi, Journal of Molecular Liquids; published by Elsevier, 2018.

Finally, the thermal stability of some novel ILs is introduced to provide more choices in high-temperature applications. In ILs mixtures, the anions and cations can combine freely. It is also feasible to predict the thermal stability of ILs mixtures by using TGA data of pure ILs. DILs have better thermal stability than their monocationic counterparts, and the influence factors of DILs structure on thermal stability are similar to monocationic ILs. Moreover, due to the stronger electrostatic interactions, DILs have a higher melting point, while adjusting the length of the linkage chain and the type of anions can obtain DILs with low melting point and high thermal stability.

Author Contributions: Conceptualization, C.X. and Z.C.; writing—review and editing, C.X.; review and editing, Z.C. All authors have read and agreed to the published version of the manuscript.

Funding: This research was funded by the National Natural Science Foundation of China (No. 21676085) and the National Key R\&D Program of China (No. 2019YFC1906705).

Data Availability Statement: Data sharing not applicable.

Conflicts of Interest: The authors declare no conflict of interest.

\section{Nomenclature}

$\begin{array}{ll}A & \text { Pre-exponential factor, } \mathrm{min}^{-1} \\ A_{\alpha} & \text { Isoconversional values of pre-exponential factor, } \mathrm{min}^{-1} \\ E & \text { Activation energy, } \mathrm{JJ} \mathrm{mol}^{-1} \\ E_{\alpha} & \text { Isoconversional values of the activation energy, } \mathrm{kJ} \mathrm{mol}^{-1} \\ f(\alpha) & \text { Kinetic model function } \\ g(\alpha) & \text { Integral kinetic model function } \\ k(T) & \text { Rate constant } \\ L & \text { Number of compounds presented in the mixture } \\ m & \text { Mass at a certain time } \\ m_{1} & \text { End mass of the sample } \\ m_{0} & \text { Initial mass } \\ m_{l} & \text { Experimental mass loss of each IL forming the mixture at each temperature } \\ m_{m i x t u r e} & \text { Mixture mass lose in an ideal case at each temperature } \\ M O T & \text { Maximum operating temperature, }{ }^{\circ} \mathrm{C} \\ R & \text { Universal gas constant, } 8.314 \mathrm{~J}^{-1} \mathrm{~K}^{-1} \\ t_{m a x} & \text { Maximum operation time } \\ T_{\text {onset }} & \text { Onset decomposition temperature, }{ }^{\circ} \mathrm{C} \\ T_{\text {peak }} & \text { Temperature of maximum degradation, }{ }^{\circ} \mathrm{C} \\ T_{50 \%} & \text { Temperature at the decomposition degree of } 50 \%,{ }^{\circ} \mathrm{C} \\ T_{z} & \text { Temperature at the decomposition degree } \mathrm{z},{ }^{\circ} \mathrm{C} \\ T_{0.01 / 10 h} & \text { Temperature at decomposition degree of } 0.01 \text { within } 10 \mathrm{~h},{ }^{\circ} \mathrm{C}\end{array}$




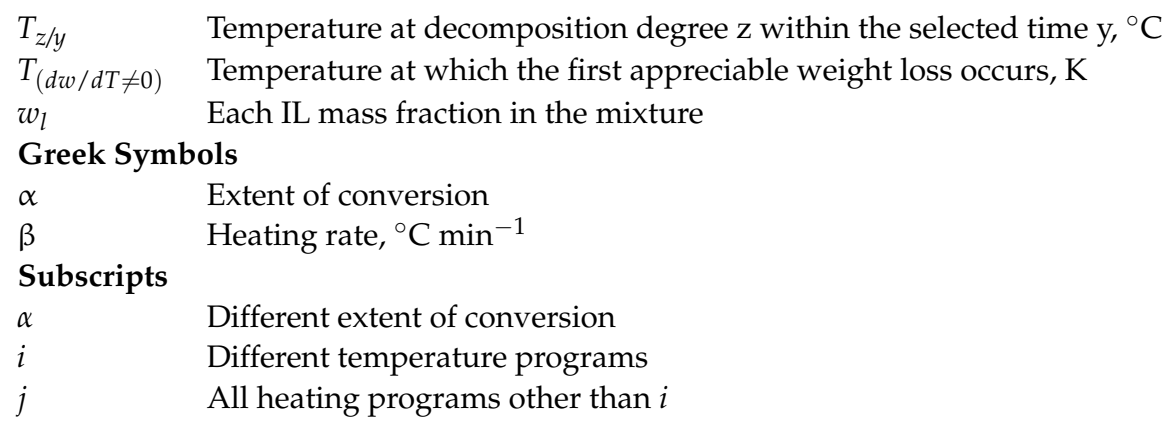

\section{References}

1. Egorova, K.S.; Ananikov, V.P. Fundamental Importance of Ionic Interactions in the Liquid Phase: A Review of Recent Studies of Ionic Liquids in Biomedical and Pharmaceutical Applications. J. Mol. Liq. 2018, 272, 271-300. [CrossRef]

2. Qiao, Y.; Ma, W.; Theyssen, N.; Chen, C.; Hou, Z. Temperature-Responsive Ionic Liquids: Fundamental Behaviors and Catalytic Applications. Chem. Rev. 2017, 117, 6881-6928. [CrossRef]

3. Borun, A. Conductance and Ionic Association of Selected Imidazolium Ionic Liquids in Various Solvents: A Review. J. Mol. Liq. 2019, 276, 214-224. [CrossRef]

4. Ichikawa, T.; Kato, T.; Ohno, H. Dimension Control of Ionic Liquids. Chem. Commun. 2019, 55, 8205-8214. [CrossRef]

5. Jiang, S.; Hu, Y.; Wang, Y.; Wang, X. Viscosity of Typical Room-Temperature Ionic Liquids: A Critical Review. J. Phys. Chem. Ref. Data 2019, 48, 033101. [CrossRef]

6. Götz, M.; Reimert, R.; Bajohr, S.; Schnetzer, H.; Wimberg, J.; Schubert, T.J.S. Long-Term Thermal Stability of Selected Ionic Liquids in Nitrogen and Hydrogen Atmosphere. Thermochim. Acta 2015, 600, 82-88. [CrossRef]

7. Amde, M.; Liu, J.-F.; Pang, L. Environmental Application, Fate, Effects, and Concerns of Ionic Liquids: A Review. Environ. Sci. Technol. 2015, 49, 12611-12627. [CrossRef] [PubMed]

8. Ghandi, K. A Review of Ionic Liquids, Their Limits and Applications. Green Sustain. Chem. 2014, 4, 44-53. [CrossRef]

9. Rybińska-Fryca, A.; Mikolajczyk, A.; Łuczak, J.; Paszkiewicz-Gawron, M.; Paszkiewicz, M.; Zaleska-Medynska, A.; Puzyn, T. How Thermal Stability of Ionic Liquids Leads to More Efficient $\mathrm{TiO}_{2}$-Based Nanophotocatalysts: Theoretical and Experimental Studies. J. Colloid Interface Sci. 2020, 572, 396-407. [CrossRef]

10. Elhamifar, D.; Kazempoor, S.; Karimi, B. Amine-Functionalized Ionic Liquid-Based Mesoporous Organosilica as a Highly Efficient Nanocatalyst for the Knoevenagel Condensation. Catal. Sci. Technol. 2016, 6, 4318-4326. [CrossRef]

11. Giacalone, F.; Gruttadauria, M. Covalently Supported Ionic Liquid Phases: An Advanced Class of Recyclable Catalytic Systems. ChemCatChem 2016, 8, 664-684. [CrossRef]

12. Oh, Y.-H.; Jang, H.B.; Im, S.; Song, M.J.; Kim, S.-Y.; Park, S.-W.; Chi, D.Y.; Song, C.E.; Lee, S. SN2 Fluorination Reactions in Ionic Liquids: A Mechanistic Study towards Solvent Engineering. Org. Biomol. Chem. 2010, 9, 418-422. [CrossRef] [PubMed]

13. Bouvet, S.; Pégot, B.; Marrot, J.; Magnier, E. Solvent Free Nucleophilic Introduction of Fluorine with [Bmim][F]. Tetrahedron Lett. 2014, 55, 826-829. [CrossRef]

14. Newington, I.; Perez-Arlandis, J.M.; Welton, T. Ionic Liquids as Designer Solvents for Nucleophilic Aromatic Substitutions. Org. Lett. 2007, 9, 5247-5250. [CrossRef] [PubMed]

15. Khan, A.S.; Man, Z.; Bustam, M.A.; Kait, C.F.; Ullah, Z.; Nasrullah, A.; Khan, M.I.; Gonfa, G.; Ahmad, P.; Muhammad, N. Kinetics and Thermodynamic Parameters of Ionic Liquid Pretreated Rubber Wood Biomass. J. Mol. Liq. 2016, 223, 754-762. [CrossRef]

16. Reina, L.; Botto, E.; Mantero, C.; Moyna, P.; Menéndez, P. Production of Second Generation Ethanol Using Eucalyptus Dunnii Bark Residues and Ionic Liquid Pretreatment. Biomass Bioenergy 2016, 93, 116-121. [CrossRef]

17. Gregorio, G.F.D.; Weber, C.C.; Gräsvik, J.; Welton, T.; Brandt, A.; Hallett, J.P. Mechanistic Insights into Lignin Depolymerisation in Acidic Ionic Liquids. Green Chem. 2016, 18, 5456-5465. [CrossRef]

18. Wang, W.; Ma, X.; Grimes, S.; Cai, H.; Zhang, M. Study on the Absorbability, Regeneration Characteristics and Thermal Stability of Ionic Liquids for VOCs Removal. Chem. Eng. J. 2017, 328, 353-359. [CrossRef]

19. Zhang, W.; Ye, L.; Jiang, J. $\mathrm{CO}_{2}$ Capture with Complex Absorbent of Ionic Liquid, Surfactant and Water. J. Environ. Chem. Eng. 2015, 3, 227-232. [CrossRef]

20. Faghihi-Zarandi, A.; Shirkhanloo, H.; Jamshidzadeh, C. A New Method for Removal of Hazardous Toluene Vapor from Air Based on Ionic Liquid-Phase Adsorbent. Int. J. Environ. Sci. Technol. 2019, 16, 2797-2808. [CrossRef]

21. Gębicki, J.; Kloskowski, A.; Chrzanowski, W.; Stepnowski, P.; Namiesnik, J. Application of Ionic Liquids in Amperometric Gas Sensors. Crit. Rev. Anal. Chem. 2016, 46, 122-138. [CrossRef] [PubMed]

22. Yin, K.; Zhang, Z.; Li, X.; Yang, L.; Tachibana, K.; Hirano, S. Polymer Electrolytes Based on Dicationic Polymeric Ionic Liquids: Application in Lithium Metal Batteries. J. Mater. Chem. A 2014, 3, 170-178. [CrossRef]

23. Varela, J.C.; Sankar, K.; Hino, A.; Lin, X.; Chang, W.; Coker, D.; Grinstaff, M. Piperidinium Ionic Liquids as Electrolyte Solvents for Sustained High Temperature Supercapacitor Operation. Chem. Commun. 2018, 54, 5590-5593. [CrossRef] [PubMed]

24. Kasprzak, D.; Stępniak, I.; Galiński, M. Acetate- and Lactate-Based Ionic Liquids: Synthesis, Characterisation and Electrochemical Properties. J. Mol. Liq. 2018, 264, 233-241. [CrossRef] 
25. Wang, X.; Jin, M.; Li, Y.; Zhao, L. The Influence of Various Ionic Liquids on the Properties of SPEEK Membrane Doped with Mesoporous Silica. Electrochim. Acta 2017, 257, 290-300. [CrossRef]

26. Wu, H.; Shen, F.; Wang, J.; Wan, Y. Membrane Fouling in Vacuum Membrane Distillation for Ionic Liquid Recycling: Interaction Energy Analysis with the XDLVO Approach. J. Membr. Sci. 2018, 550, 436-447. [CrossRef]

27. Pizzoccaro-Zilamy, M.-A.; Drobek, M.; Petit, E.; Totée, C.; Silly, G.; Guerrero, G.; Cowan, M.G.; Ayral, A.; Julbe, A. Initial Steps toward the Development of Grafted Ionic Liquid Membranes for the Selective Transport of $\mathrm{CO}_{2}$. Ind. Eng. Chem. Res. 2018, 57, 16027-16040. [CrossRef]

28. Huang, G.; Yu, Q.; Cai, M.; Zhou, F.; Liu, W. Investigation of the Lubricity and Antiwear Behavior of Guanidinium Ionic Liquids at High Temperature. Tribol. Int. 2017, 114, 65-76. [CrossRef]

29. Lee, J.; Yeo, C.-D.; Hu, Z.; Thalangama-Arachchige, V.D.; Kaur, J.; Quitevis, E.L.; Kumar, G.; Koh, Y.P.; Simon, S. Friction and Wear of Pd-Rich Amorphous Alloy (Pd43Cu27Ni10P20) with Ionic Liquid (IL) as Lubricant at High Temperatures. Metals 2019, 9, 1180. [CrossRef]

30. Li, Y.; Zhang, S.; Ding, Q.; Feng, D.; Qin, B.; Hu, L. The Corrosion and Lubrication Properties of 2-Mercaptobenzothiazole Functionalized Ionic Liquids for Bronze. Tribol. Int. 2017, 114, 121-131. [CrossRef]

31. Kaur, N. Green Synthesis of Three- to Five-Membered O-Heterocycles Using Ionic Liquids. Synth. Commun. 2018, 48, 1588-1613. [CrossRef]

32. Liu, J.; Wang, F.; Zhang, L.; Fang, X.; Zhang, Z. Thermodynamic Properties and Thermal Stability of Ionic Liquid-Based Nanofluids Containing Graphene as Advanced Heat Transfer Fluids for Medium-to-High-Temperature Applications. Renew. Energy 2014, 63, 519-523. [CrossRef]

33. Wang, W.; Wu, Z.; Li, B.; Sundén, B. A Review on Molten-Salt-Based and Ionic-Liquid-Based Nanofluids for Medium-to-High Temperature Heat Transfer. J. Therm. Anal. Calorim. 2019, 136, 1037-1051. [CrossRef]

34. Lamas, A.; Brito, I.; Salazar, F.; Graber, T.A. Synthesis and Characterization of Physical, Thermal and Thermodynamic Properties of Ionic Liquids Based on [C12mim] and [N444H] Cations for Thermal Energy Storage. J. Mol. Liq. 2016, 224, 999-1007. [CrossRef]

35. Mehrkesh, A.; Karunanithi, A.T. Optimal Design of Ionic Liquids for Thermal Energy Storage. Comput. Chem. Eng. 2016, 93, 402-412. [CrossRef]

36. Williams, M.L.; Holahan, S.P.; McCorkill, M.E.; Dickmann, J.S.; Kiran, E. Thermal and Spectral Characterization and Stability of Mixtures of Ionic Liquids [EMIM]Ac and [BMIM]Ac with Ethanol, Methanol, and Water at Ambient Conditions and at Elevated Temperatures and Pressures. Thermochim. Acta 2018, 669, 126-139. [CrossRef]

37. Patil, R.A.; Talebi, M.; Xu, C.; Bhawal, S.S.; Armstrong, D.W. Synthesis of Thermally Stable Geminal Dicationic Ionic Liquids and Related Ionic Compounds: An Examination of Physicochemical Properties by Structural Modification. Chem. Mater. 2016, 28, 4315-4323. [CrossRef]

38. Odugbesi, G.A.; Nan, H.; Soltani, M.; Davis, J.H.; Anderson, J.L. Ultra-High Thermal Stability Perarylated Ionic Liquids as Gas Chromatographic Stationary Phases for the Selective Separation of Polyaromatic Hydrocarbons and Polychlorinated Biphenyls. J. Chromatogr. A 2019, 1604, 460466. [CrossRef] [PubMed]

39. Efimova, A.; Varga, J.; Matuschek, G.; Saraji-Bozorgzad, M.R.; Denner, T.; Zimmermann, R.; Schmidt, P. Thermal Resilience of Imidazolium-Based Ionic Liquids-Studies on Short- and Long-Term Thermal Stability and Decomposition Mechanism of 1-Alkyl-3-Methylimidazolium Halides by Thermal Analysis and Single-Photon Ionization Time-of-Flight Mass Spectrometry. J. Phys. Chem. B 2018, 122, 8738-8749. [CrossRef]

40. Deferm, C.; van den Bossche, A.; Luyten, J.; Oosterhof, H.; Fransaer, J.; Binnemans, K. Thermal Stability of Trihexyl(Tetradecyl)Phosphonium Chloride. Phys. Chem. Chem. Phys. 2018, 20, 2444-2456. [CrossRef] [PubMed]

41. Patil, R.A.; Talebi, M.; Berthod, A.; Armstrong, D.W. Dicationic Ionic Liquid Thermal Decomposition Pathways. Anal. Bioanal. Chem. 2018, 410, 4645-4655. [CrossRef] [PubMed]

42. Soltani, M.; Siu, B.; Salter, E.A.; Wierzbicki, A.; West, K.N.; Davis, J.H. Synthesis, Thermal Stability, and Computed Bond Dissociation Energies of Tetraarylphosphonium-Based Mesothermal Ionic Liquids Bearing a Quinoline Ring System. Tetrahedron Lett. 2017, 58, 4628-4631. [CrossRef]

43. Siu, B.; Cassity, C.G.; Benchea, A.; Hamby, T.; Hendrich, J.; Strickland, K.J.; Wierzbicki, A.; Sykora, R.E.; Salter, E.A.; O'Brien, R.A.; et al. Thermally Robust: Triarylsulfonium Ionic Liquids Stable in Air for 90 Days at $300{ }^{\circ} \mathrm{C}$. RSC Adv. 2017, 7,7623-7630. [CrossRef]

44. Parajó, J.J.; Teijeira, T.; Fernández, J.; Salgado, J.; Villanueva, M. Thermal Stability of Some Imidazolium [NTf 2 ] Ionic Liquids: Isothermal and Dynamic Kinetic Study through Thermogravimetric Procedures. J. Chem. Thermodyn. 2017, 112, 105-113. [CrossRef]

45. Maton, C.; Vos, N.D.; Stevens, C.V. Ionic Liquid Thermal Stabilities: Decomposition Mechanisms and Analysis Tools. Chem. Soc. Rev. 2013, 42, 5963-5977. [CrossRef]

46. Al-Sallami, W.; Parsaeian, P.; Neville, A. An Appraisal of the Thermal Decomposition Mechanisms of ILs as Potential Lubricants. Lubr. Sci. 2019, 31, 229-238. [CrossRef]

47. Salgado, J.; Villanueva, M.; Parajó, J.J.; Fernández, J. Long-Term Thermal Stability of Five Imidazolium Ionic Liquids. J. Chem. Thermodyn. 2013, 65, 184-190. [CrossRef]

48. Blanco, D.; Bartolomé, M.; Ramajo, B.; Viesca, J.L.; González, R.; Hernández Battez, A. Isoconversional Kinetic Analysis Applied to Five Phosphonium Cation-Based Ionic Liquids. Thermochim. Acta 2017, 648, 62-74. [CrossRef] 
49. Blanco, D.; Oulego, P.; Ramos, D.; Fernández, B.; Cuetos, J.M. Model-Free Kinetics Applied to Evaluate the Long-Term Thermal Stability of Three [NTf2] Anion-Based Ionic Liquids. Thermochim. Acta 2017, 656, 70-84. [CrossRef]

50. Seeberger, A.; Andresen, A.-K.; Jess, A. Prediction of Long-Term Stability of Ionic Liquids at Elevated Temperatures by Means of Non-Isothermal Thermogravimetrical Analysis. Phys. Chem. Chem. Phys. 2009, 11, 9375. [CrossRef] [PubMed]

51. Salgado, J.; Parajó, J.J.; Fernández, J.; Villanueva, M. Long-Term Thermal Stability of Some 1-Butyl-1-Methylpyrrolidinium Ionic Liquids. J. Chem. Thermodyn. 2014, 74, 51-57. [CrossRef]

52. Wooster, T.J.; Johanson, K.M.; Fraser, K.J.; MacFarlane, D.R.; Scott, J.L. Thermal Degradation of Cyano Containing Ionic Liquids. Green Chem. 2006, 8, 691. [CrossRef]

53. Quraishi, K.S.; Bustam, M.A.; Krishnan, S.; Khan, M.I.; Wilfred, C.D.; Lévêque, J.-M. Thermokinetics of Alkyl Methylpyrrolidinium [NTf2] Ionic Liquids: Effect of Alkyl Chain on Thermal Stability. J. Therm. Anal. Calorim. 2017, 129, 261-270. [CrossRef]

54. Ullah, Z.; Bustam, M.A.; Man, Z.; Khan, A.S. Thermal Stability and Kinetic Study of Benzimidazolium Based Ionic Liquid. Procedia Eng. 2016, 148, 215-222. [CrossRef]

55. Huang, Z.; Wang, X.; Lu, T.; Nong, D.; Zhao, J.; Wei, M.; Teng, L.; Teng, L. Isoconversional Kinetic Analysis of Thermal Decomposition of 1-Butyl-3-Methylimidazolium Hexafluorophosphate under Inert Nitrogen and Oxidative Air Atmospheres. J. Therm. Anal. Calorim. 2019, 140, 695-712. [CrossRef]

56. Jiang, H.-C.; Lin, W.-C.; Hua, M.; Pan, X.-H.; Shu, C.-M.; Jiang, J.-C. Analysis of Thermal Stability and Pyrolysis Kinetic of Dibutyl Phosphate-Based Ionic Liquid through Thermogravimetry, Gas Chromatography/Mass Spectrometry, and Fourier Transform Infrared Spectrometry. J. Therm. Anal. Calorim. 2019, 138, 489-499. [CrossRef]

57. Williams, M.L.; Dickmann, J.S.; McCorkill, M.E.; Hassler, J.C.; Kiran, E. The Kinetics of Thermal Decomposition of 1-Alkyl3-Methylimidazolium Chloride Ionic Liquids under Isothermal and Non-Isothermal Conditions. Thermochim. Acta 2020, 685, 178509. [CrossRef]

58. Akçay, A.; Balci, V.; Uzun, A. Structural Factors Controlling Thermal Stability of Imidazolium Ionic Liquids with 1- $\mathrm{n}$-Butyl-3Methylimidazolium Cation on $\gamma$-Al 2 O 3. Thermochim. Acta 2014, 589, 131-136. [CrossRef]

59. Makhoukhi, B.; Villemin, D.; Didi, M.A. Synthesis of Bisimidazolium-Ionic Liquids: Characterization, Thermal Stability and Application to Bentonite Intercalation. J. Taibah Univ. Sci. 2016, 10, 168-180. [CrossRef]

60. Mezzetta, A.; Łuczak, J.; Woch, J.; Chiappe, C.; Nowicki, J.; Guazzelli, L. Surface Active Fatty Acid ILs: Influence of the Hydrophobic Tail and/or the Imidazolium Hydroxyl Functionalization on Aggregates Formation. J. Mol. Liq. 2019, 289, 111155. [CrossRef]

61. Song, Y.; Xia, Y.; Liu, Z. Influence of Cation Structure on Physicochemical and Antiwear Properties of Hydroxyl-Functionalized Imidazolium Bis(Trifluoromethylsulfonyl)Imide Ionic Liquids. Tribol. Trans. 2012, 55, 738-746. [CrossRef]

62. Chen, Y.; Mu, T. Thermal Stability of Ionic Liquids. In Encyclopedia of Ionic Liquids; Zhang, S., Ed.; Springer: Singapore, 2020; pp. 1-13. ISBN 978-981-10-6739-6.

63. Parajó, J.J.; Villanueva, M.; Otero, I.; Fernández, J.; Salgado, J. Thermal Stability of Aprotic Ionic Liquids as Potential Lubricants. Comparison with Synthetic Oil Bases. J. Chem. Thermodyn. 2018, 116, 185-196. [CrossRef]

64. Zhang, L.; Wei, L.; Zhai, S.; Zhao, D.; Sun, J.; An, Q. Hydrogen Bond Promoted Thermal Stability Enhancement of Acetate Based Ionic Liquid. Chin. J. Chem. Eng. 2020, S1004954120300847. [CrossRef]

65. Monteiro, B.; Maria, L.; Cruz, A.; Carretas, J.M.; Marçalo, J.; Leal, J.P. Thermal Stability and Specific Heats of Coordinating Ionic Liquids. Thermochim. Acta 2020, 684, 178482. [CrossRef]

66. Rotrekl, J.; Jandová, V.; Storch, J.; Velíšek, P.; Cuř́inová, P.; Schwarz, J.; Wagner, Z.; Bendová, M. Thermal Properties of Novel Oligoether-Substituted Ionic Liquids and the Influence of Alkyl-Substituent Isomery. Fluid Phase Equilibria 2020, 514, 112561. [CrossRef]

67. Kuhn, B.L.; Osmari, B.F.; Heinen, T.M.; Bonacorso, H.G.; Zanatta, N.; Nielsen, S.O.; Ranathunga, D.T.S.; Villetti, M.A.; Frizzo, C.P. Dicationic Imidazolium-Based Dicarboxylate Ionic Liquids: Thermophysical Properties and Solubility. J. Mol. Liq. 2020, 308, 112983. [CrossRef]

68. Thasneema, K.K.; Thayyil, M.S.; Rosalin, T.; Elyas, K.K.; Dipin, T.; Sahu, P.K.; Krishna Kumar, N.S.; Saheer, V.C.; Messali, M.; Hadda, T.B. Thermal and Spectroscopic Investigations on Three Phosphonium Based Ionic Liquids for Industrial and Biological Applications. J. Mol. Liq. 2020, 307, 112960. [CrossRef]

69. Talebi, M.; Patil, R.A.; Armstrong, D.W. Physicochemical Properties of Branched-Chain Dicationic Ionic Liquids. J. Mol. Liq. 2018, 256, 247-255. [CrossRef]

70. Navarro, P.; Larriba, M.; Rojo, E.; García, J.; Rodríguez, F. Thermal Properties of Cyano-Based Ionic Liquids. J. Chem. Eng. Data 2013, 58, 2187-2193. [CrossRef]

71. Efimova, A.; Pfützner, L.; Schmidt, P. Thermal Stability and Decomposition Mechanism of 1-Ethyl-3-Methylimidazolium Halides. Thermochim. Acta 2015, 604, 129-136. [CrossRef]

72. Eshetu, G.G.; Jeong, S.; Pandard, P.; Lecocq, A.; Marlair, G.; Passerini, S. Comprehensive Insights into the Thermal Stability, Biodegradability, and Combustion Chemistry of Pyrrolidinium-Based Ionic Liquids. ChemSusChem 2017, 10, 3146-3159. [CrossRef]

73. Parajó, J.J.; Villanueva, M.; Troncoso, J.; Salgado, J. Thermophysical Properties of Choline and Pyridinium Based Ionic Liquids as Advanced Materials for Energy Applications. J. Chem. Thermodyn. 2020, 141, 105947. [CrossRef]

74. Cao, Y.; Mu, T. Comprehensive Investigation on the Thermal Stability of 66 Ionic Liquids by Thermogravimetric Analysis. Ind. Eng. Chem. Res. 2014, 53, 8651-8664. [CrossRef] 
75. De la Hoz, A.T.; Brauer, U.G.; Miller, K.M. Physicochemical and Thermal Properties for a Series of 1-Alkyl-4-Methyl-1,2,4Triazolium Bis(Trifluoromethylsulfonyl)Imide Ionic Liquids. J. Phys. Chem. B 2014, 118, 9944-9951. [CrossRef] [PubMed]

76. Lorenzo, M.; Vilas, M.; Verdía, P.; Villanueva, M.; Salgado, J.; Tojo, E. Long-Term Thermal Stabilities of Ammonium Ionic Liquids Designed as Potential Absorbents of Ammonia. RSC Adv. 2015, 5, 41278-41284. [CrossRef]

77. Bhattacharyya, S.; Shah, F.U. Thermal Stability of Choline Based Amino Acid Ionic Liquids. J. Mol. Liq. 2018, 266, 597-602. [CrossRef]

78. Brauer, U.G.; De la Hoz, A.T.; Miller, K.M. The Effect of Counteranion on the Physicochemical and Thermal Properties of 4-Methyl-1-Propyl-1,2,4-Triazolium Ionic Liquids. J. Mol. Liq. 2015, 210, 286-292. [CrossRef]

79. Feng, W.; Lu, Y.; Chen, Y.; Lu, Y.; Yang, T. Thermal Stability of Imidazolium-Based Ionic Liquids Investigated by TG and FTIR Techniques. J. Therm. Anal. Calorim. 2016, 125, 143-154. [CrossRef]

80. Navarro, P.; Larriba, M.; García, J.; Rodríguez, F. Thermal Stability and Specific Heats of $\{[$ Emim] $[$ DCA $]+[$ Emim $][T C M]\}$ Mixed Ionic Liquids. Thermochim. Acta 2014, 588, 22-27. [CrossRef]

81. Shah, F.U.; Khan, I.A.; Johansson, P. Comparing the Thermal and Electrochemical Stabilities of Two Structurally Similar Ionic Liquids. Molecules 2020, 25, 2388. [CrossRef]

82. Zhang, J.; Song, L.; Li, K.; An, Q.; Ma, H.; Yang, L.; Wei, L. Water Addition Enhanced Thermal Stability of Alkylimidazolium Acetate in Ionosolv Treatment of Lignin. Int. J. Biol. Macromol. 2019, 141, 1055-1064. [CrossRef] [PubMed]

83. Oster, K.; Goodrich, P.; Jacquemin, J.; Hardacre, C.; Ribeiro, A.P.C.; Elsinawi, A. A New Insight into Pure and Water-Saturated Quaternary Phosphonium-Based Carboxylate Ionic Liquids: Density, Heat Capacity, Ionic Conductivity, Thermogravimetric Analysis, Thermal Conductivity and Viscosity. J. Chem. Thermodyn. 2018, 121, 97-111. [CrossRef]

84. Saikat, M.S.H.; Islam, M.M.; Mollah, M.Y.A.; Susan, M.A.B.H.; Miran, M.S. Thermal and Electrochemical Properties of Protic Ionic Liquids and Their Binary Mixtures with Water. Mater. Today Proc. 2019, 15, 498-503. [CrossRef]

85. Yamaki, N.; Shiota, K.; Izato, Y.; Hoang, D.K.; Miyake, A. Thermal Hazard Analysis of a Biomass Pretreatment Process Using Ionic Liquids. J. Therm. Anal. Calorim. 2019, 138, 2945-2953. [CrossRef]

86. Muhammad, A. Thermal and Kinetic Analysis of Pure and Contaminated Ionic Liquid: 1-Butyl-2.3-Dimethylimidazolium Chloride (BDMIMCl). Pol. J. Chem. Technol. 2016, 18, 122-125. [CrossRef]

87. Vyazovkin, S. Modification of the Integral Isoconversional Method to Account for Variation in the Activation Energy. J. Comput. Chem. 2001, 22, 178-183. [CrossRef]

88. Vyazovkin, S.; Burnham, A.K.; Criado, J.M.; Pérez-Maqueda, L.A.; Popescu, C.; Sbirrazzuoli, N. ICTAC Kinetics Committee Recommendations for Performing Kinetic Computations on Thermal Analysis Data. Thermochim. Acta 2011, 520, 1-19. [CrossRef]

89. Friedman, H.L. Kinetics of Thermal Degradation of Char-Forming Plastics from Thermogravimetry. Application to a Phenolic Plastic. J. Polym. Sci. C Polym. Symp. 1964, 6, 183-195. [CrossRef]

90. Volli, V.; Lin, W.-C.; Krishna, G.V.S.; Bhardwaj, H.; Shu, C.-M. Oxidative Stability, Thermal Hazard Analysis, and Decomposition Kinetics of 1-Methylimidazolium Nitrate via DSC, TGA, and GC/MS. J. Therm. Anal. Calorim. 2019, 138, 3403-3413. [CrossRef]

91. Starink, M.J. The Determination of Activation Energy from Linear Heating Rate Experiments: A Comparison of the Accuracy of Isoconversion Methods. Thermochim. Acta 2003, 404, 163-176. [CrossRef]

92. Flynn, J.H.; Wall, L.A. General Treatment of the Thermogravimetry of Polymers. J. Res. Natl. Bur. Stand. Phys. Chem. 1966, 70A. [CrossRef]

93. Ozawa, T. A New Method of Analyzing Thermogravimetric Data. BCSJ 1965, 38, 1881-1886. [CrossRef]

94. Akahira, T.; Sunose, T. Method of Determining Activation Deterioration Constant of Electrical Insulating Materials. Res. Rep. Chiba Inst. Technol. 1971, 16, 22-31.

95. Coats, A.W.; Redfern, J.P. Kinetic Parameters from Thermogravimetric Data. Nature 1964, 201, 68-69. [CrossRef]

96. Starink, M.J. A New Method for the Derivation of Activation Energies from Experiments Performed at Constant Heating Rate. Thermochim. Acta 1996, 288, 97-104. [CrossRef]

97. Vyazovkin, S. A Unified Approach to Kinetic Processing of Nonisothermal Data. Int. J. Chem. Kinet. 1996, 28, 95-101. [CrossRef]

98. Vyazovkin, S.; Dollimore, D. Linear and Nonlinear Procedures in Isoconversional Computations of the Activation Energy of Nonisothermal Reactions in Solids. J. Chem. Inf. Comput. Sci. 1996, 36, 42-45. [CrossRef]

99. Vyazovkin, S. Evaluation of Activation Energy of Thermally Stimulated Solid-State Reactions under Arbitrary Variation of Temperature. J. Comput. Chem. 1997, 18, 393-402. [CrossRef]

100. Heym, F.; Korth, W.; Thiessen, J.; Kern, C.; Jess, A. Evaporation and Decomposition Behavior of Pure and Supported Ionic Liquids under Thermal Stress. Chem. Ing. Tech. 2015, 87, 791-802. [CrossRef]

101. Liu, S.; Chen, Y.; Shi, Y.; Sun, H.; Zhou, Z.; Mu, T. Investigations on the Thermal Stability and Decomposition Mechanism of an Amine-Functionalized Ionic Liquid by TGA, NMR, TG-MS Experiments and DFT Calculations. J. Mol. Liq. 2015, 206, 95-102. [CrossRef]

102. Criado, J.M.; Málek, J.; Ortega, A. Applicability of the Master Plots in Kinetic Analysis of Non-Isothermal Data. Thermochim. Acta 1989, 147, 377-385. [CrossRef]

103. Málek, J. The Kinetic Analysis of Non-Isothermal Data. Thermochim. Acta 1992, 200, 257-269. [CrossRef]

104. Thomas, E.; Vijayalakshmi, K.P.; George, B.K. Kinetic Stability of Imidazolium Cations and Ionic Liquids: A Frontier Molecular Orbital Approach. J. Mol. Liq. 2019, 276, 721-727. [CrossRef]

105. Daily, L.A.; Miller, K.M. Correlating Structure with Thermal Properties for a Series of 1-Alkyl-4-Methyl-1,2,4-Triazolium Ionic Liquids. J. Org. Chem. 2013, 78, 4196-4201. [CrossRef] [PubMed] 
106. Gusain, R.; Bakshi, P.S.; Panda, S.; Sharma, O.P.; Gardas, R.; Khatri, O.P. Physicochemical and Tribophysical Properties of Trioctylalkylammonium Bis(Salicylato)Borate (N888n-BScB) Ionic Liquids: Effect of Alkyl Chain Length. Phys. Chem. Chem. Phys. 2017, 19, 6433-6442. [CrossRef] [PubMed]

107. Montanino, M.; Carewska, M.; Alessandrini, F.; Passerini, S.; Appetecchi, G.B. The Role of the Cation Aliphatic Side Chain Length in Piperidinium Bis(Trifluoromethansulfonyl)Imide Ionic Liquids. Electrochim. Acta 2011, 57, 153-159. [CrossRef]

108. Özdemir, M.C.; Özgün, B. Phenyl/Alkyl-Substituted-3,5-Dimethylpyrazolium Ionic Liquids. J. Mol. Liq. 2014, 200, 129-135. [CrossRef]

109. Greeson, K.T.; Hall, N.G.; Redeker, N.D.; Marcischak, J.C.; Gilmore, L.V.; Boatz, J.A.; Le, T.C.; Alston, J.R.; Guenthner, A.J.; Ghiassi, K.B. Synthesis and Properties of Symmetrical N,N'-Bis(Alkyl)Imidazolium Bromotrichloroferrate(III) Paramagnetic, Room Temperature Ionic Liquids with High Short-Term Thermal Stability. J. Mol. Liq. 2018, 265, 701-710. [CrossRef]

110. Tao, R.; Tamas, G.; Xue, L.; Simon, S.L.; Quitevis, E.L. Thermophysical Properties of Imidazolium-Based Ionic Liquids: The Effect of Aliphatic versus Aromatic Functionality. J. Chem. Eng. Data 2014, 59, 2717-2724. [CrossRef]

111. Krasovskiy, V.G.; Chernikova, E.A.; Glukhov, L.M.; Kapustin, G.I.; Koroteev, A.A. Effect of Hydroxyl Groups in a Cation Structure on the Properties of Ionic Liquids. Russ. J. Phys. Chem. A 2018, 92, 2379-2385. [CrossRef]

112. Ferreira, M.L.; Araujo, J.M.M.; Vega, L.F.; Llovell, F.; Pereiro, A.B. Functionalization of Fluorinated Ionic Liquids: A Combined Experimental-Theoretical Study. J. Mol. Liq. 2020, 302, 112489. [CrossRef]

113. Xue, Z.; Zhang, Y.; Zhou, X.; Cao, Y.; Mu, T. Thermal Stabilities and Decomposition Mechanism of Amino- and HydroxylFunctionalized Ionic Liquids. Thermochim. Acta 2014, 578, 59-67. [CrossRef]

114. Coadou, E.; Goodrich, P.; Neale, A.R.; Timperman, L.; Hardacre, C.; Jacquemin, J.; Anouti, M. Synthesis and Thermophysical Properties of Ether-Functionalized Sulfonium Ionic Liquids as Potential Electrolytes for Electrochemical Applications. Chemphyschem 2016, 17, 3992-4002. [CrossRef]

115. Mahrova, M.; Conte, M.; Roman, E.; Nevshupa, R. Critical Insight into Mechanochemical and Thermal Degradation of Imidazolium-Based Ionic Liquids with Alkyl and Monomethoxypoly(Ethylene Glycol) Side Chains. J. Phys. Chem. C 2014, 118, 22544-22552. [CrossRef]

116. de Miguel, I.; Morales, E.; Herradón, B.; del Río, C.; Mann, E. Synthesis and Characterization of Oligo(Oxyethylene)Functionalized Thiazolium Based Room Temperature Ionic Liquids. Tetrahedron Lett. 2016, 57, 3291-3293. [CrossRef]

117. Nokami, T.; Yamashita, T.; Komura, T.; Handa, N.; Shimizu, M.; Yamaguchi, K.; Domi, Y.; Usui, H.; Sakaguchi, H.; Itoh, T. Effects of the Ether Oxygen Atom in Alkyl Side Chains on the Physical Properties of Piperidinium Ionic Liquids. Faraday Discuss. 2017, 206, 523-534. [CrossRef] [PubMed]

118. Ngo, H.L.; LeCompte, K.; Hargens, L.; McEwen, A.B. Thermal Properties of Imidazolium Ionic Liquids. Thermochim. Acta 2000, 357, 97-102. [CrossRef]

119. Clough, M.T.; Geyer, K.; Hunt, P.A.; Mertes, J.; Welton, T. Thermal Decomposition of Carboxylate Ionic Liquids: Trends and Mechanisms. Phys. Chem. Chem. Phys. 2013, 15, 20480-20495. [CrossRef] [PubMed]

120. Rotrekl, J.; Storch, J.; Kloužek, J.; Vrbka, P.; Husson, P.; Andresová, A.; Bendová, M.; Wagner, Z. Thermal Properties of 1-Alkyl-3Methylimidazolium Bis(Trifluoromethylsulfonyl)Imide Ionic Liquids with Linear, Branched and Cyclic Alkyl Substituents. Fluid Phase Equilibria 2017, 443, 32-43. [CrossRef]

121. Gusain, R.; Khatri, O.P. Fatty Acid Ionic Liquids as Environmentally Friendly Lubricants for Low Friction and Wear. RSC Adv. 2016, 6, 3462-3469. [CrossRef]

122. Xue, Z.; Qin, L.; Jiang, J.; Mu, T.; Gao, G. Thermal, Electrochemical and Radiolytic Stabilities of Ionic Liquids. Phys. Chem. Chem. Phys. 2018, 53. [CrossRef] [PubMed]

123. Lethesh, K.C.; Shah, S.N.; Ayodele, O.B.; Mutalib, M.I.A.; Uemura, Y. Nitrile-Functionalized Azepanium Ionic Liquids: Synthesis Characterization and Thermophysical Properties. J. Mol. Liq. 2016, 221, 1140-1144. [CrossRef]

124. Huang, G.; Lin, W.-C.; He, P.; Pan, Y.; Shu, C.-M. Thermal Decomposition of Imidazolium-Based Ionic Liquid Binary Mixture: Processes and Mechanisms. J. Mol. Liq. 2018, 272, 37-42. [CrossRef]

125. Clough, M.T.; Crick, C.R.; Gräsvik, J.; Hunt, P.A.; Niedermeyer, H.; Welton, T.; Whitaker, O.P. A Physicochemical Investigation of Ionic Liquid Mixtures. Chem. Sci. 2015, 6, 1101-1114. [CrossRef]

126. Navarro, P.; Larriba, M.; García, J.; Rodríguez, F. Thermal Stability, Specific Heats, and Surface Tensions of ([Emim][DCA]+[4empy][Tf2N]) Ionic Liquid Mixtures. J. Chem. Thermodyn. 2014, 76, 152-160. [CrossRef]

127. Navarro, P.; Larriba, M.; Beigbeder, J.-B.; García, J.; Rodríguez, F. Thermal Stability and Specific Heats of \{[Bpy][BF4] + [Bpy][Tf2N]\} and $\{[\mathrm{Bpy}][\mathrm{BF} 4]+[4 \mathrm{bmpy}][\mathrm{Tf} 2 \mathrm{~N}]\}$ Mixed Ionic Liquid Solvents. J. Therm. Anal. Calorim. 2015, 119, 1235-1243. [CrossRef]

128. Larriba, M.; Navarro, P.; Beigbeder, J.-B.; García, J.; Rodríguez, F. Mixing and Decomposition Behavior of $\{[4 \mathrm{bmpy}][\mathrm{Tf} 2 \mathrm{~N}]+[\mathrm{Emim}][\mathrm{EtSO} 4]\}$ and $\{[4 \mathrm{bmpy}][\mathrm{Tf} 2 \mathrm{~N}]+[$ Emim][TFES]\} Ionic Liquid Mixtures. J. Chem. Thermodyn. 2015, 82, 58-75. [CrossRef]

129. Liu, J.; Yang, W.; Li, Z.; Ren, F.; Hao, H. Experimental Investigation of Thermo-Physical Properties of Geminal Dicationic Ionic Compounds for Latent Thermal Energy Storage. J. Mol. Liq. 2020, 307, 112994. [CrossRef]

130. Javaherian, M.; Saghanezhad, S.J. Synthesis, Characterization and Applications of Dicationic Ionic Liquids in Organic Synthesis. MROC 2020, 17, 450-464. [CrossRef]

131. Zaky, M.T.; Nessim, M.I.; Deyab, M.A. Synthesis of New Ionic Liquids Based on Dicationic Imidazolium and Their Anti-Corrosion Performances. J. Mol. Liq. 2019, 290, 111230. [CrossRef]

132. Cognigni, A.; Kampichler, S.; Bica, K. Surface-Active Ionic Liquids in Catalysis: Impact of Structure and Concentration on the Aerobic Oxidation of Octanol in Water. J. Colloid Interface Sci. 2017, 492, 136-145. [CrossRef] 
133. Montalbán, M.G.; Víllora, G.; Licence, P. Ecotoxicity Assessment of Dicationic versus Monocationic Ionic Liquids as a More Environmentally Friendly Alternative. Ecotoxicol. Environ. Saf. 2018, 150, 129-135. [CrossRef]

134. Bender, C.; Kuhn, B.; Farias, C.; Ziembowicz, F.; Beck, T.; Frizzo, C. Thermal Stability and Kinetic of Decomposition of Mono- and Dicationic Imidazolium-Based Ionic Liquids. J. Braz. Chem. Soc. 2019. [CrossRef]

135. Mezzetta, A.; Perillo, V.; Guazzelli, L.; Chiappe, C. Thermal Behavior Analysis as a Valuable Tool for Comparing Ionic Liquids of Different Classes. J. Therm. Anal. Calorim. 2019, 138, 3335-3345. [CrossRef]

136. Shirota, H.; Mandai, T.; Fukazawa, H.; Kato, T. Comparison between Dicationic and Monocationic Ionic Liquids: Liquid Density, Thermal Properties, Surface Tension, and Shear Viscosity. J. Chem. Eng. Data 2011, 56, 2453-2459. [CrossRef]

137. Fareghi-Alamdari, R.; Hatefipour, R. Low Viscosity Azide-Containing Mono and Dicationic Ionic Liquids with Unsaturated Side Chain. J. Mol. Liq. 2017, 225, 793-799. [CrossRef]

138. Payagala, T.; Huang, J.; Breitbach, Z.S.; Sharma, P.S.; Armstrong, D.W. Unsymmetrical Dicationic Ionic Liquids: Manipulation of Physicochemical Properties Using Specific Structural Architectures. Chem. Mater. 2007, 19, 5848-5850. [CrossRef]

139. Zhang, H.; Li, M.; Yang, B. Design, Synthesis, and Analysis of Thermophysical Properties for Imidazolium-Based Geminal Dicationic Ionic Liquids. J. Phys. Chem. C 2018, 122, 2467-2474. [CrossRef]

140. Boumediene, M.; Haddad, B.; Paolone, A.; Drai, M.; Villemin, D.; Rahmouni, M.; Bresson, S.; Abbas, O. Synthesis, Thermal Stability, Vibrational Spectra and Conformational Studies of Novel Dicationic Meta-Xylyl Linked Bis-1-Methylimidazolium Ionic Liquids. J. Mol. Struct. 2019, 1186, 68-79. [CrossRef]

141. Clarke, C.J.; Bui-Le, L.; Hallett, J.P.; Licence, P. Thermally-Stable Imidazolium Dicationic Ionic Liquids with Pyridine Functional Groups. ACS Sustain. Chem. Eng. 2020, 8, 8762-8772. [CrossRef]

142. Krasovskiy, V.G.; Kapustin, G.I.; Gorbatsevich, O.B.; Glukhov, L.M.; Chernikova, E.A.; Koroteev, A.A.; Kustov, L.M. Properties of Dicationic Disiloxane Ionic Liquids. Molecules 2020, 25, 2949. [CrossRef] [PubMed] 